Article

\title{
Pyridine-Containing Macrocycles Display MMP-2/9 Inhibitory Activity and Distinct Effects on Migration and Invasion of 2D and 3D Breast Cancer Models
}

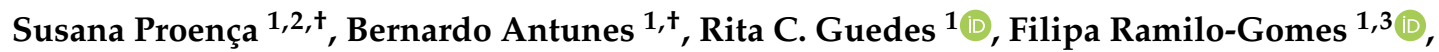 \\ M. Fátima Cabral ${ }^{1}$, Judite Costa ${ }^{1}$, Ana S. Fernandes ${ }^{4}\left(\mathbb{D}\right.$, Matilde Castro ${ }^{1}$, Nuno G. Oliveira ${ }^{1}$ and \\ Joana P. Miranda ${ }^{1, t, *}$ \\ 1 Research Institute for Medicines (iMed.ULisboa), Faculty of Pharmacy, Universidade de Lisboa, 1649-003 \\ Lisbon, Portugal; s.proenca@uu.nl (S.P.); bernardoantunes_94@hotmail.com (B.A.); \\ rguedes@ff.ulisboa.pt (R.C.G.); filipa.ramilo.gomes@tecnico.ulisboa.pt (F.R.-G.); fcabral@ff.ul.pt (M.F.C.); \\ jcosta@ff.ul.pt (J.C.); mcastro@ff.ul.pt (M.C.); ngoliveira@ff.ul.pt (N.G.O.) \\ 2 Institute for Risk Assessment Sciences, Utrecht University, P.O. Box 80177, 3508TD Utrecht, The Netherlands \\ 3 Centro de Química Estrutural, Instituto Superior Técnico, Universidade de Lisboa, 1049-001 Lisbon, Portugal \\ 4 CBIOS, University Lusófona, 1749-024 Lisbon, Portugal; ana.fernandes@ulusofona.pt \\ * Correspondence: jmiranda@ff.ul.pt \\ + These authors contributed equally to this work.
}

Received: 13 September 2019; Accepted: 9 October 2019; Published: 15 October 2019

\begin{abstract}
The role of metalloproteinases (MMPs) on the migration and invasion of cancer cells has been correlated with tumor aggressiveness, namely with the up-regulation of MMP-2 and 9 . Herein, two pyridine-containing macrocyclic compounds, [15]pyN $\mathrm{p}_{5}$ and [16]py $\mathrm{N}_{5}$, were synthesized, chemically characterized and evaluated as potential MMP inhibitors for breast cancer therapy using 3D and 2D cellular models. [15] $\mathrm{pyN}_{5}$ and [16] $\mathrm{pyN}_{5}(5-20 \mu \mathrm{M})$ showed a marked inhibition of MMPs activity $(100 \%$ at concentrations $\geq 7.5 \mu \mathrm{M})$ when compared to ARP-100, a known MMP inhibitor. The inhibitory activity of [15]pyN $\mathrm{N}_{5}$ and [16]pyN $\mathrm{N}_{5}$ was further supported through in silico docking studies using Goldscore and ChemPLP scoring functions. Moreover, although no significant differences were observed in the invasion studies in the presence of all MMPs inhibitors, cell migration was significantly inhibited by both pyridine-containing macrocycles at concentrations above $5 \mu \mathrm{M}$ in $2 \mathrm{D}$ cells $(p<0.05)$. In spheroids, the same effect was observed, but only with [16]pyN $\mathrm{N}_{5}$ at $20 \mu \mathrm{M}$ and ARP-100 at $40 \mu \mathrm{M}$. Overall, [15]pyN $\mathrm{N}_{5}$ and [16]pyN $\mathrm{N}_{5}$ led to impaired breast cancer cell migration and revealed to be potential inhibitors of MMPs 2 and 9 .
\end{abstract}

Keywords: pyridine-containing macrocyclic; molecular docking studies; 3D models; breast cancer; MMP inhibitors; migration and invasion

\section{Introduction}

Matrix metalloproteinases (MMPs) have been found to correlate with increased breast tumor aggressiveness [1-5]. During metastization, tumor cells recruit ECM (extracellular matrix) proteases, such as MMPs, to their leading edge for localized proteolysis of the ECM net [1-5]. MMPs are highly conserved proteins containing a structural $\mathrm{Zn}^{2+}$ ion and one to three $\mathrm{Ca}^{2+}$ ions, and in their catalytic domain a catalytic $\mathrm{Zn}^{2+}$ ion coordinated through the conserved motif HExGHxxGxxH [6]. Other common structures to MMPs are their hemopexin-like C-terminal domain essential for its non-proteolytic functions, and a pro-peptide domain which coordinates the catalytic $\mathrm{Zn}^{2+}$ ion maintaining MMPs latency, being its cleavage required for activation [6,7]. Although grouped according to their ECM substrate and domain organization, MMPs have a substantial substrate 
overlapping, being able to virtually cleave any ECM component, and in some cases, growth factors, cell adhesion molecules and other proteases precursors [8-10]. Development of MMPs inhibitors has thus been attempted within the framework of cancer therapy, including breast cancer [11].

Although initially promising, the first and second generations of MMP inhibitors were not clinically efficient due to issues related to their administration route [12] and the promotion of side effects such as the musculoskeletal syndrome (MSS) [13], respectively. Therefore, the following generation of inhibitory compounds was designed focusing on specific structures of MMP-2 and 9 gelatinases [14,15], namely giving a major emphasis to the S1'pocket, a differential structure among MMPs. A set of new molecules screened for MMP inhibitory activity were developed using the arylsulfonamide group, contained in the prinomastat, as structural model $[16,17]$. From this study, ARP-100 (Figure 1A) showed to be the most promising inhibitor, considering both its potency for MMP-2 inhibition and its selectivity for this MMP over MMP-1, 3 and 7. Following the hypothesis that the MSS side effects and lack of efficiency from the earlier MMPi were due to the zinc-binding group hydroxamic acid, studying alternative zinc-binding groups poses itself as a pertinent approach. Indeed, Jacobsen et al. [18] showed that aza-macrocyles have an improved MMP-3 inhibition potency when compared with one of the most common zinc binding groups, the acetohydroxamic acid (AHA). Macrocyclic compounds have also been described as potentially more specific than open chain chelators due to its ring rigidity, which constrains the type of metal that may be coordinated [19]. On the other hand, these macrocycles are much more selective, as they do not inhibit the non-heme iron enzyme soybean lipoxygenase. Two pentaaza-macrocyles containing pyridine in their backbone, [15]pyN $\mathrm{N}_{5}$ and [16] $\mathrm{pyN}_{5}$ [20], synthesized (Figure 1B) and characterized by our group (Figures S1 and S2, Tables S1 and S2), display high stability constants for $\mathrm{Zn}^{2+}$. In a previous report we also demonstrated the protective chelating properties of [15] $\mathrm{pyN}_{5}$ in the context of the cytotoxicity of cadmium(II), another group 12 element [21]. Moreover, the copper(II) complex of [15]py $\mathrm{N}_{5}$ was also previously studied as a superoxide dismutase mimic (SODm), modulating ROS and protecting MCF-10A (non-malignant cell line) from oxaliplatin treatment while increasing cytotoxicity of this drug in breast cancer cell line MCF-7 [22].

$A$
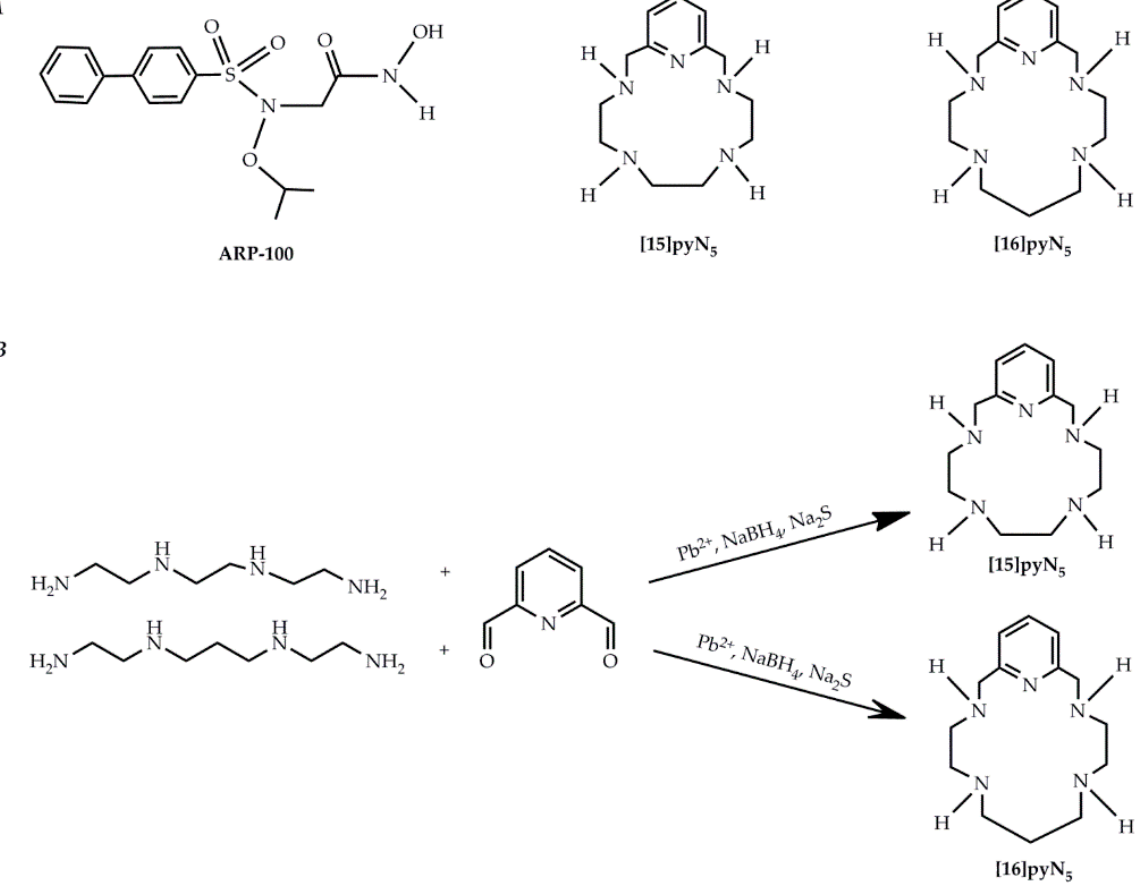

Figure 1. Pyridine containing macrocyclic compounds and ARP100 (A) chemical structures; and (B) schematic synthesis of [15]pyN $\mathrm{p}_{5}$ and [16] $\mathrm{pyN}_{5}$. 
Additionally, it is also obvious that representative cell models and a set of adequate complementary migration and invasion endpoints are required for a better prediction of the impact of the novel gelatinase inhibitors in metastization. Three-dimensional (3D) cancer cell cultures have gained an increased interest in the field of biomedicine. A representative example are the spheroids that consist of compact cell aggregates that recapitulate in vivo cell-adhesion profile and better represent ECM-cell interactions [23]. In fact, the cell adhesion molecules $\beta$-integrins and E-cadherin have critical roles in the resistance to chemotherapeutics, and in overall malignancy [24-26]. Spheroids can also mimic the gradient of nutrients and oxygen that occurs in avascular tumor nodules, in some cases displaying a hypoxic region and even necrotic cores, giving rise to distinct cell populations: proliferating, quiescent and necrotic $[23,25]$. Cells from spheroids have shown transcriptomic differences in enzymes involved in mitochondrial metabolism, redox reactions and downregulation of a DNA mismatch repair enzyme, associated with acquired resistance to alkylating agents [27-29]. Moreover, spheroids respond differently than monolayers to compounds targeting epithelial-mesenchymal transition (EMT), as they present more stemness-related traits and proteins associated to metastization, hence being regarded as very suitable models for migration and invasion studies [24,26,30,31].

The work herein performed represents thus a comprehensive multidisciplinary study evaluating the effect of these pyridine containing-pentaaza macrocycles in the widely used invasive breast cancer MDA-MB-231 cells, in both 3D and 2D cultures, using different migration and invasion endpoints. The outcome of [15]pyN $\mathrm{N}_{5}$ and [16]pyN $\mathrm{N}_{5}$ macrocycles on MMP-2 and 9 activity was assessed by applying a modified gelatin zymography gel assay (Figure 2). To gain additional insights on the mechanism underlying the inhibitory activity, docking studies were also performed using two different scoring functions (ChemPLP and GoldScore) in order to predict protein-ligand interactions and binding modes of [15]pyN $\mathrm{N}_{5}$ and [16]pyN 5 on MMP-2 and MMP-9 active site.

1

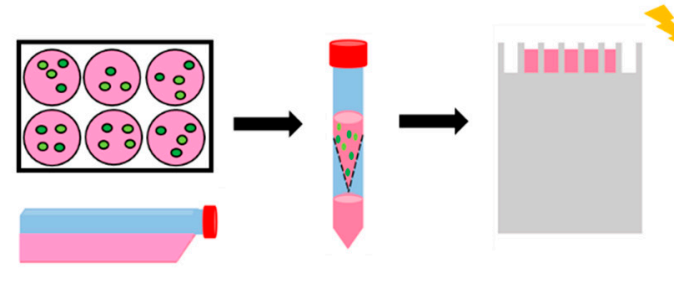

4

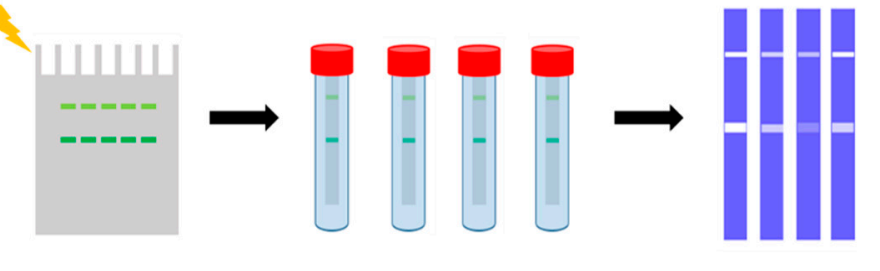

Figure 2. Schematic representation of the modified gelatine zymography assay. (1) 2D (CM2D) and 3D (CM3D) cultures conditioning in serum free media for $24 \mathrm{~h}$; (2) CM2D/3D collection and concentration (100×); (3) CM2D/3D analyzed by SDS-PAGE containing $0.1 \%$ gelatine as substrate; (4) developing buffer incubation step of individual lanes with [15]pyN $\mathrm{N}_{5}$, [16]pyN $\mathrm{N}_{5}$ and ARP-100; (5) staining with Coomassie Brilliant Blue solution.

\section{Results}

\subsection{Viable Spheroids were Obtained from MDA-MB-231 Cells}

A suspension culture-based system using ULA plates was successfully developed, as viable three-dimensional (3D) spheroids were obtained from MDA-MB-231 cells. Moreover, spheroid diameter increased during culture time, reaching a diameter of $191 \mu \mathrm{m}$ at day 4 of culture (Figure 3A,B). At this point, the histological analysis of spheroid cryosections was performed to evaluate spheroid morphology. H\&E staining of sections revealed solid spheroids, with cells homogeneously distributed and embedded in extracellular matrix (Figure 3C). Immunolabeling with proliferative marker Ki-67 (Figure 3D) showed a percentage of approximately $15 \%$ proliferating cells, which together with the MTS assay and total protein quantification data (Figure 3E) indicates a low proliferative profile of MDA-MB-231 cells when cultured under 3D cultures, a pattern that has been previously reported in the literature $[32,33]$. 

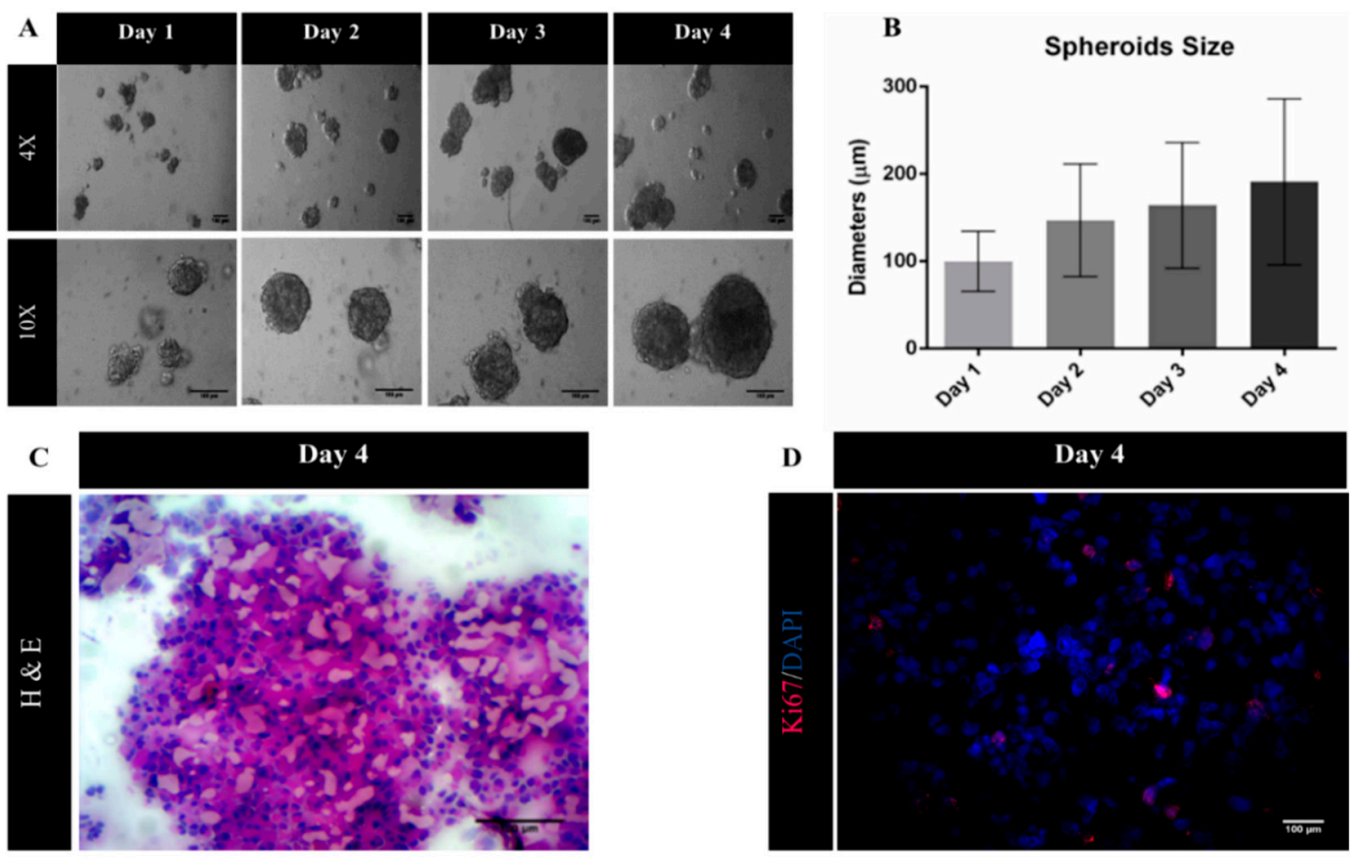

E

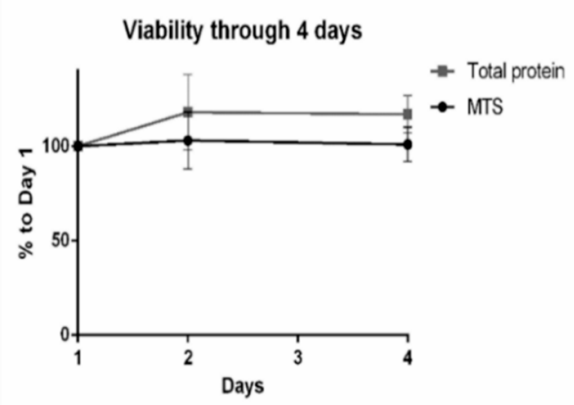

Figure 3. Characterization of MDA-MB-231 spheroids. (A) Representative phase contrast images of MDA-MB-231 spheroids from day 1 to day 4 . Scale bars $=100 \mu \mathrm{m} ;($ B $)$ spheroids diameters $(\mu \mathrm{m})$ from day 1 to day 4 represented as mean $\pm \operatorname{SD}(n=3)$; (C) Hematoxylin and Eosin (H\&E) staining of MDA-MB-231 spheroid sections. Scale bar $=100 \mu \mathrm{m}$; (D) representative immunofluorescence images of day 4 of MDA-MB-231 spheroid cryosections labelled with Ki-67 (red). Nuclei were labelled with DAPI (blue). Scale bars $=100 \mu \mathrm{m}$; (E) cell viability/proliferation up to day 4 relative to day 1 of culture, expressed in percentage (mean $\pm \mathrm{SEM}, n=3$ ).

2.2. [15]pyN $N_{5},[16] p y N_{5}$ and ARP-100 Present a Differential Cytotoxic Profile in $2 D$ and $3 D$ Cultures of $M D A-M B-231$

To evaluate the cytotoxicity of the macrocycles [15]pyN $\mathrm{N}_{5}$ and [16]py $\mathrm{N}_{5}$, dose-response curves were performed for MDA-MB-231 in both 2D and 3D cultures. The commercially available compound ARP-100 was also studied in the same conditions as a control (Figure 4). Given that the migration assays are performed in serum free conditions, the same conditions were adopted for the cytotoxicity assays. ARP-100 concentrations within the range of $1-100 \mu \mathrm{M}$ were chosen according to the literature [34,35], being the same concentration used for [15]py $\mathrm{N}_{5}$ and [16]pyN $\mathrm{N}_{5}$ compounds.

As shown in Figure 4, in 2D, despite the cytotoxicity observed, cell viability was higher than $74 \%$ $(p<0.001)$ for concentrations up to $75 \mu \mathrm{M}$, decreasing to $\sim 60 \%$ at $100 \mu \mathrm{M}$ concentrations $(p<0.001)$ for both macrocyclic compounds. Concerning the 3D models, the cytotoxicity profile of the compounds was less pronounced, with cell viability always above $80 \%$ (n.s.). ARP-100 showed no cytotoxic effects in monolayer cultures for concentrations up to $25 \mu \mathrm{M}$ (Figure 4). At a concentration of $50 \mu \mathrm{M}$, cell viability was $75 \%(p<0.001)$, decreasing afterwards in a concentration dependent manner, showing a viability of $44 \%$ at $100 \mu \mathrm{M}$ concentration of the compound $(p<0.001)$ (Figure 4$)$. 
[15]pyN5

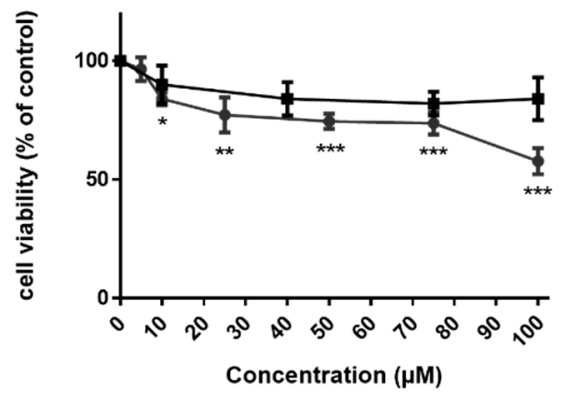

[16]pyN5

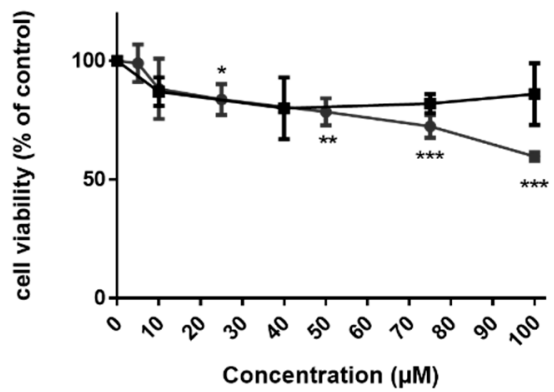

ARP-100

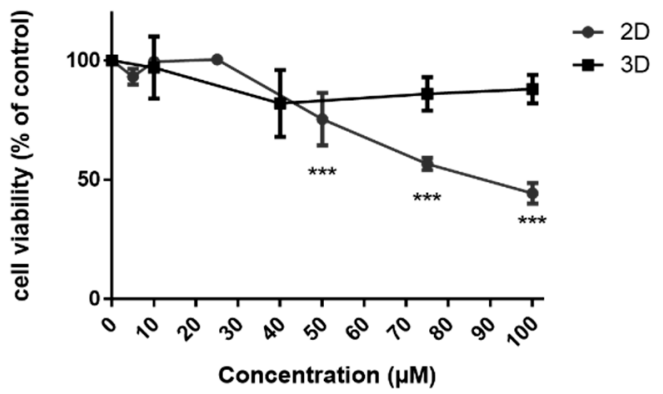

Figure 4. Effect of [15] $\mathrm{pyN}_{5},[16] \mathrm{pyN}_{5}$ and ARP-100 on MDA-MB-231 cell viability/proliferation on $2 \mathrm{D}$ and $3 \mathrm{D}$ models. Data expressed as percentage (mean $\pm \mathrm{SD}, n=3-4$ ) relative to respective controls (non-treated condition for [15]pyN $\mathrm{N}_{5}$ and [16]pyN $\mathrm{N}_{5}$ and $0.25 \%$ DMSO for ARP-100). Statistical significance is represented as ${ }^{*} p<0.05,{ }^{* *} p<0.01,{ }^{* * *} p<0.001$.

\subsection{MDA-MB-231 Reveal a Culture-Dependent MMP-2/9 Secretion Profile}

MMPs are secreted by the cells. As such, the gelatinolytic activity of MMP-2/9 was analyzed by gelatin zymography in MDA-MB-231 conditioned medium (CM) obtained from both two-dimensional monolayer (CM2D) and three-dimensional spheroid cultures (CM3D).

Firstly, relevant parameters such as the conditioning time (24, 48, 72 or $96 \mathrm{~h}), \mathrm{CM}$ concentration and quantity of total protein of $\mathrm{CM}$ to be loaded in the gels were optimized. Moreover, culture volume was adjusted accordingly, in order to obtain a conditioning volume per cell in 3D cultures as in the two-dimensional system. The adopted ratio was of $\sim 200,000$ cells $/ \mathrm{mL}$. As conditioning periods longer than $24 \mathrm{~h}$ in serum free conditions resulted in increased cell death (30\% cell death with $0.25 \%$ DMSO in a 48-h incubation period - data not shown), a conditioning incubation period not exceeding $24 \mathrm{~h}$ was established. Furthermore, a volume concentration of $\sim 100 \times$ was adopted to ensure sufficient gelatinase concentration.

CM3D and CM2D zymography profiles showed a consistent differential MMP-2 and 9 activity, being MMP-2 and MMP-9 activities two-fold higher in CM2D and CM3D, respectively (Figure 5A,B). Importantly, the inhibition with EDTA $(7.8 \mathrm{mM})$ confirmed that the MMP-2 (the band at $72 \mathrm{kDa}$ and $66 \mathrm{kDa}$ correspond to the pro- and active-form, respectively) and MMP-9 (the band at $92 \mathrm{kDa}$ and $83 \mathrm{kDa}$ correspond to the pro- and active-form, respectively) corresponding bands were indeed MMPs (Figure S3).

\subsection{MMP Gelatinase Activity is Inhibited by the Macrocycles [15]pyN $N_{5}$ and [16]pyN 5}

SDS has been pointed out as a disrupting agent of TIMP-MMP binding in zymography assays, rendering in these cases the observed gelatinolytic activity independent of the TIMP (tissue inhibitors of matrix metalloproteinase) content [36]. To ensure the tested compounds would not be released from the proteins in the SDS-PAGE gel [37], as may occur for TIMPs, modifications were introduced in the zymography technique (modified zymography—Figure 2). 
A

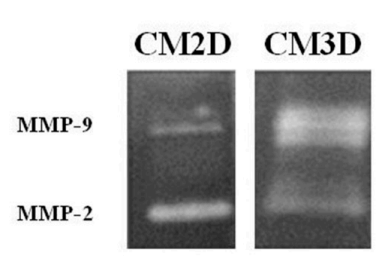

B

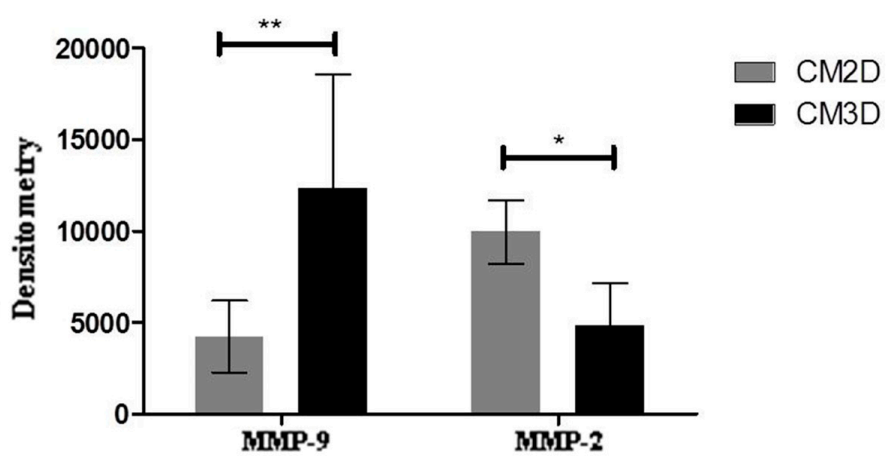

CM3D
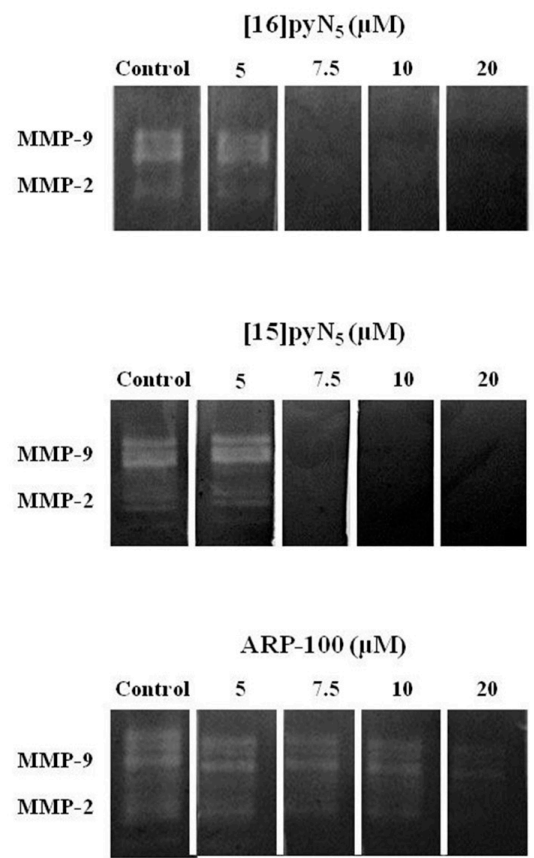

Figure 5. Gelatinase zymography assay. (A) Gel zymogram depicting differences in MMP-2 and MMP-9 content in CM2D and CM3D; (B) densitometric quantification of MMP-2 and MMP-9 gelatinolytic activity of CM2D and CM3D. Data expressed as mean $\pm \mathrm{SD}(n=3-4)$. Statistical significance is represented as ${ }^{*} p<0.05$ and ${ }^{* *} p<0.01$; (C) representative zymograms of CM2D/3D incubated with $5-20 \mu \mathrm{M}$ of [16]pyN $\mathrm{N}_{5}$, [15]pyN $\mathrm{p}_{5}$ and ARP-100 in the developing buffer.

As such, the technique herein adopted differs from the classical zymography particularly in the developing buffer incubation step, as the compounds were dissolved in the developing buffer and then incubated with the gels containing the $\mathrm{CM}$ (modified zymography-Figure 2); whereas in the classical zymography the compounds are incubated directly with cells.

In our modified protocol, changes in band intensity reveal the direct effect of [15]pyN $\mathrm{p}_{5},[16] \mathrm{pyN}_{5}$ and ARP-100 in the MMP-2/9 gelatinolytic activity in CM2D and CM3D (Figure 5C). The macrocyclic compounds showed a more potent gelatinase inhibitory effect than ARP-100. For [16]pyN $\mathrm{N}_{5}$ a $100 \%$ inhibition of MMP-2/9 was observed for concentrations above $7.5 \mu \mathrm{M}$ (Figure 5C) in both CM2D and CM3D. Similarly, a 100\% inhibitory effect for MMP-2/9 was observed with [15]pyN $\mathrm{N}_{5}$ for concentrations above $7.5 \mu \mathrm{M}$ and $10 \mu \mathrm{M}$ in CM3D and CM2D, respectively (Figure 5C); whereas complete inhibition 
was not achieved with ARP-100 at any concentration studied. Importantly, a higher inhibitory effect of ARP-100 was observed for MMP-2 reflecting the specificity of ARP-100 for MMP-2.

In addition, the values of $\mathrm{pZn}^{2+}$ vs. the concentration of [15]pyN $\mathrm{N}_{5}$ and [16]pyN $\mathrm{N}_{5}$, were simulated resorting to the Hyss program (Figure 6) [38], using the compounds stability constants for $\mathrm{Zn}^{2+}$ and species distribution. The equivalence point obtained in the simulation matched the steep obtained in the zymography assay, suggesting a correlation between the chelation of free $\mathrm{Zn}^{2+}$ and the inhibition of gelatinases by the compounds.

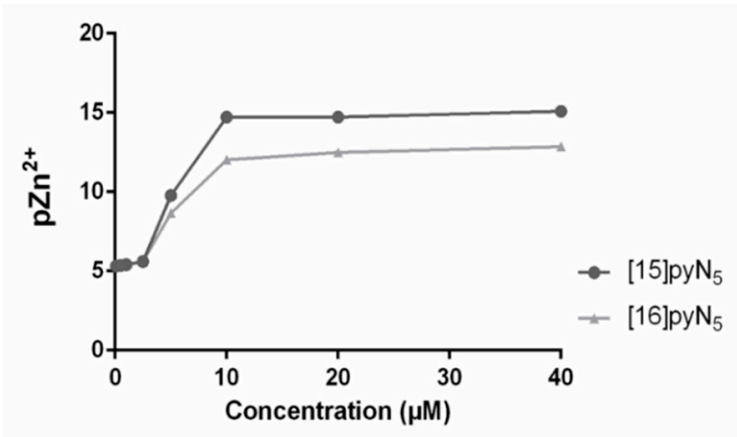

Figure 6. Values of $\mathrm{pZn}^{2+}\left(-\log \left[\mathrm{Zn}^{2+}\right]\right)$, calculated for an aqueous solution of $\mathrm{pH} 7.4$ containing $\mathrm{Zn}^{2+}(5 \mu \mathrm{M})$ and [16]pyN 5 and [15]pyN $\mathrm{N}_{5}(0.1-40 \mu \mathrm{M})$.

\subsection{Macrocycles [15]pyN $N_{5}$ and [16]pyN $N_{5}$ Interact with the Catalytic Zinc and its Coordinating Amino Acids}

In silico docking studies were performed to better understand the molecular mechanism of interactions of [15]pyN $\mathrm{N}_{5}$ and [16] $\mathrm{pyN}_{5}$ with MMP-2 and MMP-9. The reference inhibitor ARP-100 was also docked in the same conditions.

Regarding MMP-2, docking studies reveal that [15]pyN $\mathrm{N}_{5}$ and [16]py $\mathrm{N}_{5}$ mainly occupied the pocket $\mathrm{S1}^{\prime}$ (Figure 7). One of the nitrogen atoms from the compounds interact with the catalytic $\mathrm{Zn}^{2+}$ and possesses similar distances when compared with ARP-100 (2.4 vs. 2.1-2.6 $⿱$ ). An interaction between the phenyl group of [15] $\mathrm{pyN}_{5}$ and [16] $\mathrm{pyN}_{5}$ and the imidazole group of His120 (from MMP-2) was found in a distance similar to the reference inhibitor ([15]py $\mathrm{N}_{5}$ and [16]pyN $\mathrm{p}_{5} \sim 3.0-3.6 / 3.8-3.8 \AA$ vs. ARP-100 3.0-3.5 A- Table 1). This interaction plays an important role in stabilization of the molecules into the catalytic site. Other favorable hydrophobic interactions are observed with Leu82, Val117 and His84 (Table 1).

Finally, some MMP-2 known inhibitors were also docked. It was shown, for MMP-2 structure, that the known inhibitors occupy mainly the $\mathrm{S1}^{\prime}$ pocket, interacting with $\mathrm{Zn}^{2+}$ ion $(\sim 2.0 \AA$ - Table S3). According to the results, the known inhibitors interact with His120 ( $\pi-\pi$ interaction), Leu82 (H-acceptor) and Val117 similarly to [15] $\mathrm{pyN}_{5}$ and [16]pyN $\mathrm{N}_{5}$ compounds. Besides that, some important interactions are observed with S3 pocket amino acids (Tyr73, His84 and Phe86) of MMP-2 (Table S3).

Concerning MMP-9, [15]pyN $\mathrm{p}_{5}$ and [16] $\mathrm{pyN}_{5}$ present an interesting pose, occupying mainly the opposite region to S1' (Figure 7). The $\mathrm{Zn}^{2+}$ distance varies between $2.6 \AA$ for ARP-100 and 4.0-4.4 $\AA$ to [15]pyN $\mathrm{N}_{5}$ and [16]pyN $\mathrm{N}_{5}$ (Table 1). As depicted in Figure 7 the phenyl groups of ARP-100 occupy S1'pocket: a $\pi-\pi$ interaction appears between these groups and the imidazole group of His226. Tyr248, an amino acid located on the opposite region of the S1'pocket, also interacts with ARP-100. It was also observed an H-bond formation with Leu188 and a strong interaction with Ala189 and Leu187. These interactions revealed to be similar to the binding interaction observed for [15]py $\mathrm{N}_{5}$ and [16]pyN $\mathrm{N}_{5}$. Overall, relevant interactions, with similar distances, were observed between the molecules [15]pyN $\mathrm{N}_{5}$, [16]pyN $\mathrm{N}_{5}$ and ARP-100 and the important amino acids of the binding pocket of MMP-9. 
Table 1. Docking results: score values and interaction distances (in $\AA$ ) between [15]py $\mathrm{N}_{5}$, [16]pyN and ARP-100 with MMP-2 and MMP-9 using ChemPLP Scoring function.

\begin{tabular}{|c|c|c|c|c|}
\hline & & {$[15] p y N_{5}$} & {$[16] p y N_{5}$} & ARP-100 \\
\hline \multirow{8}{*}{ MMP-2 } & Score & 53.1 & 53.3 & 93.2 \\
\hline & $\mathrm{Zn}^{2+}$ & 2.1 & 2.6 & 2.4 \\
\hline & His120 & 3.6 & 3.8 & 3.5 \\
\hline & Leu82 & 4.7 & 4.4 & 2.9 \\
\hline & Val117 & 3.8 & 3.0 & 3.7 \\
\hline & His84 & 3.7 & 3.3 & 3.4 \\
\hline & Tyr73 & 9.0 & 10.0 & 8.9 \\
\hline & Phe86 & 8.3 & 8.8 & 6.3 \\
\hline \multirow{7}{*}{ MMP-9 } & Score & 34.8 & 42.0 & 90.0 \\
\hline & $\mathrm{Zn}^{2+}$ & 4.0 & 4.4 & 2.6 \\
\hline & Leu187 & 3.1 & 4.0 & 3.9 \\
\hline & Leu188 & 6.1 & 6.4 & 3.2 \\
\hline & Ala189 & 3.0 & 4.0 & 3.1 \\
\hline & His226 & 5.2 & 6.5 & 3.4 \\
\hline & Try248 & 9.8 & 10.8 & 3.6 \\
\hline
\end{tabular}

A
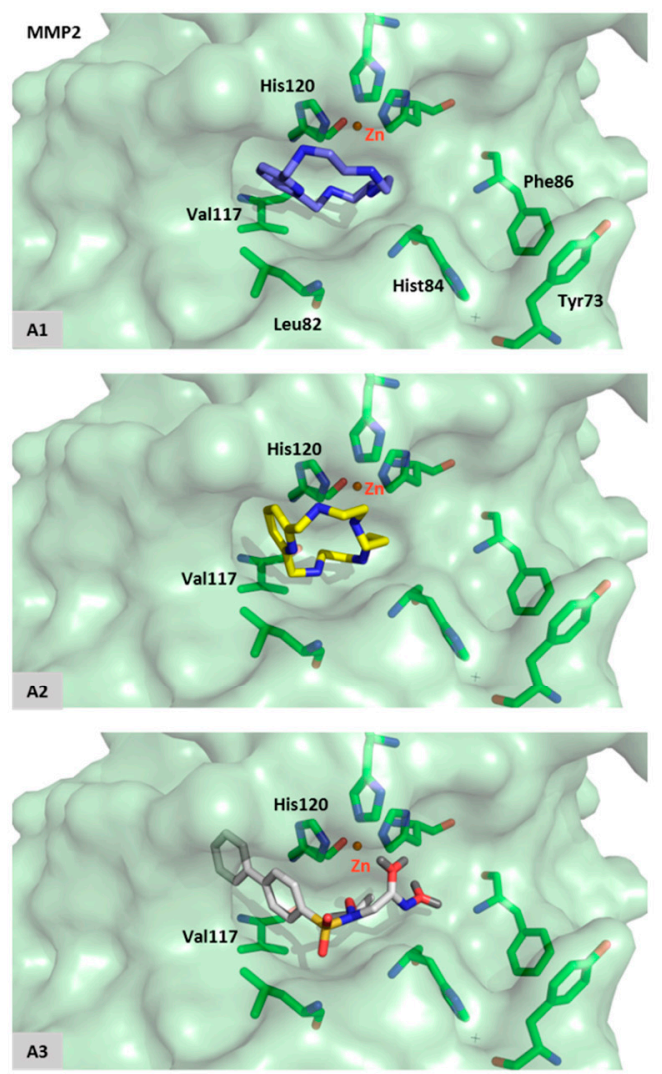

B
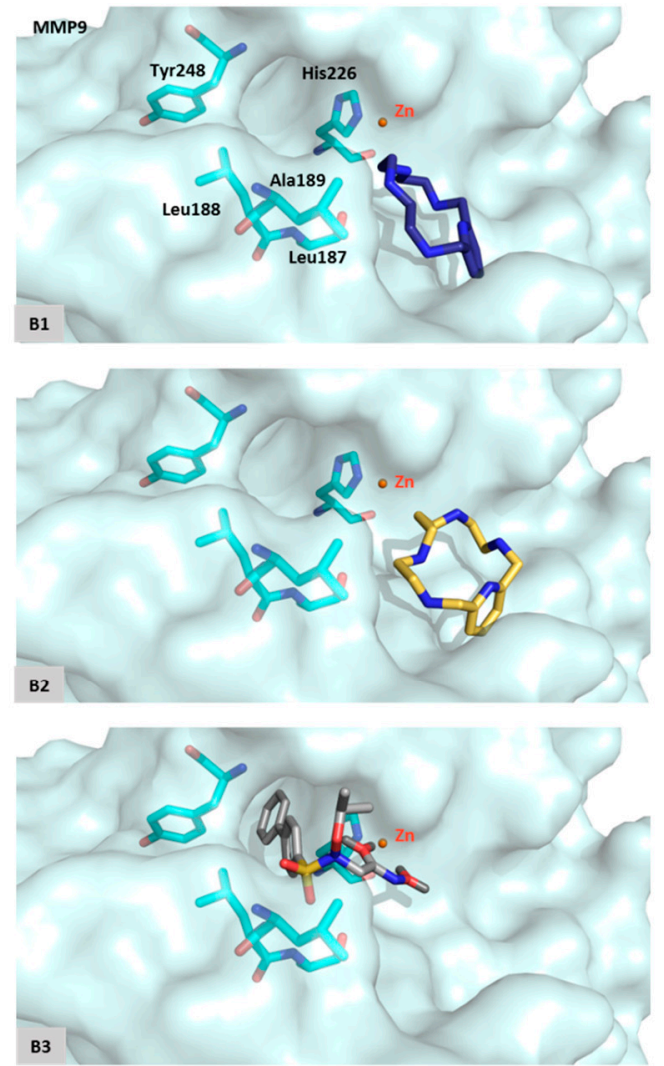

Figure 7. Docking poses. (A) MMP-2 active site with [15]pyN $\mathrm{p}_{5}$ (A1), [16]pyN 5 (A2) and ARP-100 (A3); (B) MMP-9 active site with [15]pyN $\mathrm{N}_{5}$ (B1), [16]pyN $\mathrm{N}_{5}$ (B2) and ARP-100 (B3). 


\subsection{Cell migration is Significantly Impaired by [15]py $\mathrm{N}_{5}$ and [16]py $\mathrm{N}_{5}$}

To evaluate the effect of the test compounds in cancer cell migration, scratch and radial migration assays were performed in 2D and 3D cultures, respectively, exposed to [16]py $\mathrm{N}_{5},[15]$ pyN $\mathrm{N}_{5}$ and ARP-100.

In monolayer cultures, scratch assays were performed in serum-free conditions, so that the closure of the scratch would result of cell migration instead of proliferation. Herein, a significant inhibitory effect was observed for both macrocyclic compounds, when comparing to the non-treated control condition. For concentrations as low as $5 \mu \mathrm{M}$ (non-cytotoxic) [16]py $\mathrm{N}_{5}$ and [15]pyN $\mathrm{N}_{5}$ reduced cell migration $38 \pm 2 \%(p<0.001)$ and $21 \pm 4 \%(p<0.05)$, respectively (Figure 8A,B). ARP-100, on the other hand, when compared to the corresponding control ( $0.25 \%$ DMSO), did not induce a significant inhibitory effect on cell migration at any concentration tested (Figure $8 \mathrm{~A}, \mathrm{~B}$ ).

$\mathbf{A}$
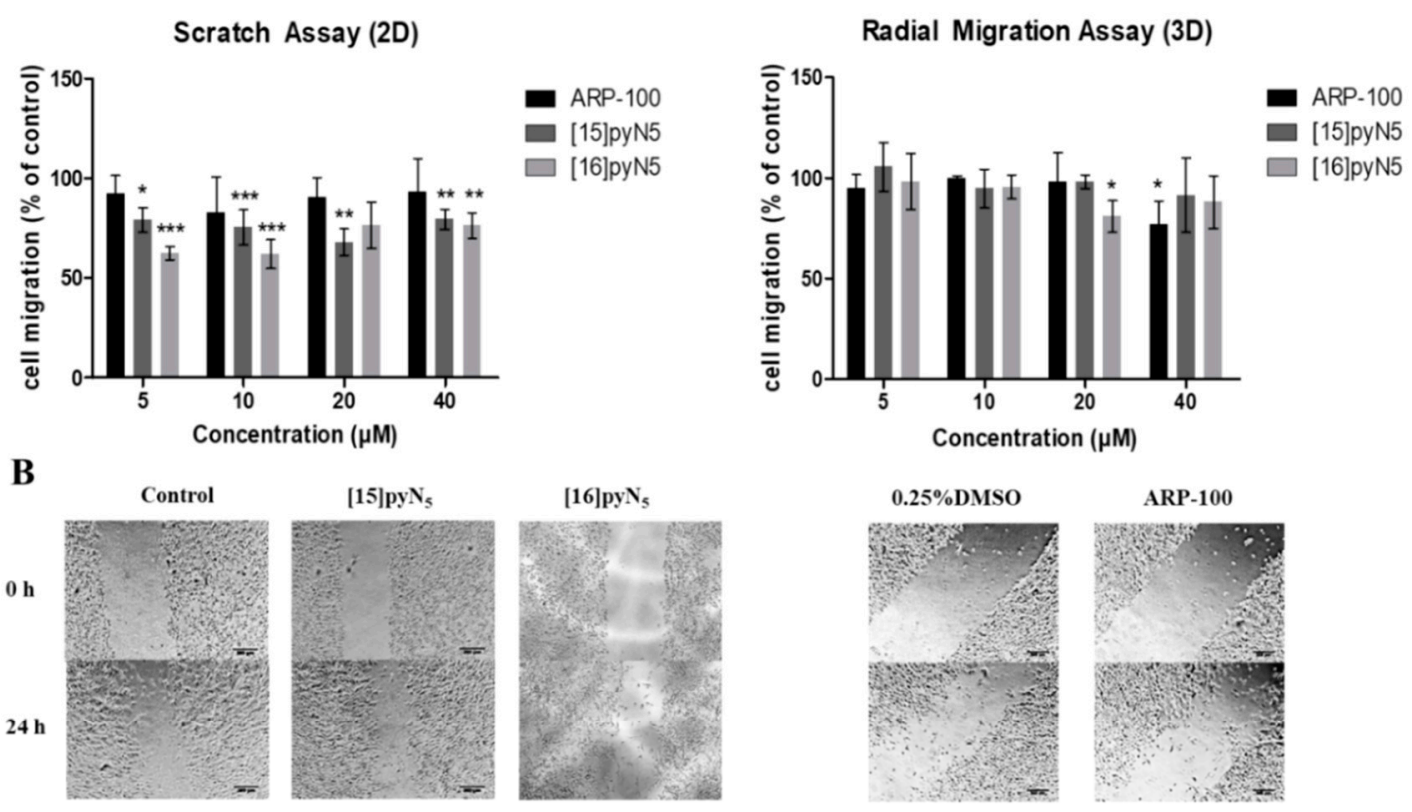

\section{c}
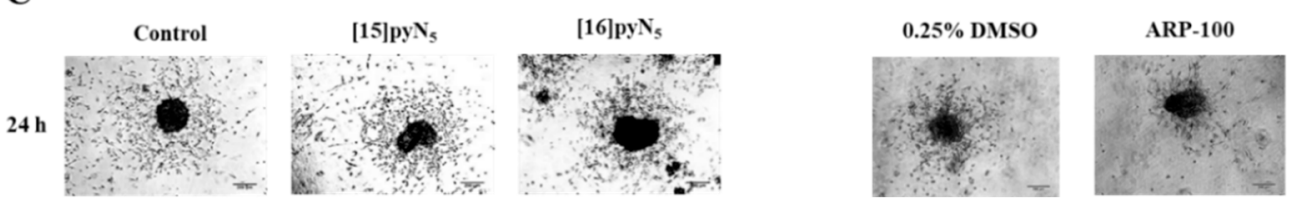

Figure 8. Effect of [15]pyN $\mathrm{N}_{5},[16] \mathrm{pyN}_{5}$ and ARP-100 in cell migration in 2D (scratch) and 3D (radial migration) models. (A) Quantification of migrated cells after 24h in 2D and 3D models of MDA-MB-231 cells. Data expressed as percentage (mean $\pm \mathrm{SD}, n=3-4$ ) relative to controls (non-treated condition for [15]pyN $\mathrm{N}_{5}$ and [16]pyN $\mathrm{N}_{5}$ and $0.25 \%$ DMSO for ARP-100); (B) representative images of scratch assays after 0 and $24 \mathrm{~h}$ upon incubation with $20 \mu \mathrm{M}$ of each compound and respective controls, scale bars $=200 \mu \mathrm{m}$; (C) representative images of radial migration after $24 \mathrm{~h}$ upon incubation with $20 \mu \mathrm{M}$ of each compound and respective controls. Magnification $4 \times$, scale bars $=200 \mu \mathrm{m}$. Statistical significance is represented as ${ }^{*} p<0.05,{ }^{* *} p<0.01,{ }^{* * *} p<0.001$.

For the radial migration assays, 10\% FBS supplemented medium was adopted, as serum-free medium alone hampered cell migration ability (data not shown). As depicted in Figure 8A,C, both [15] $\mathrm{pyN}_{5}$ and [16]pyN $\mathrm{N}_{5}$ macrocycles were not particularly effective in decreasing spheroid migration. In fact, only [16]pyN $\mathrm{N}_{5}$ at a concentration of $20 \mu \mathrm{M}$ was able to show a significant effect with cell 
migration decreasing $20 \pm 4 \%(p<0.05)$. Similarly, treatment with ARP-100 resulted in a significant cell migration decrease of $23 \pm 3 \%$ relative to control ( $0.25 \%$ DMSO) only at $40 \mu \mathrm{M}(p<0.05)$.

\subsection{Breast Cancer Cell Invasion Ability is Maintained upon Exposure to [15]pyN $N_{5}$ and [16]pyN}

The invasion ability of MDA-MB-231 2D cultures in the presence of the compounds was performed through a chemotaxis assay, using transwell inserts coated with Matrigel, which mimics the presence of extracellular matrix that cells have to degrade in order to invade surrounding tissues. In spheroid cultures, radial invasion assays were adopted.

Herein, the macrocyclic compounds and ARP-100 showed no significant inhibitory effect on cancer cell invasion (Figure 9). Nevertheless, spheroids treated with ARP-100 revealed a slight decrease of 14\% on its invasion ability at $24 \mathrm{~h}$ when compared to non-treated condition (n.s.) (Figure 9). This decrease was already observed at $16 \mathrm{~h}$ (data not shown).

A
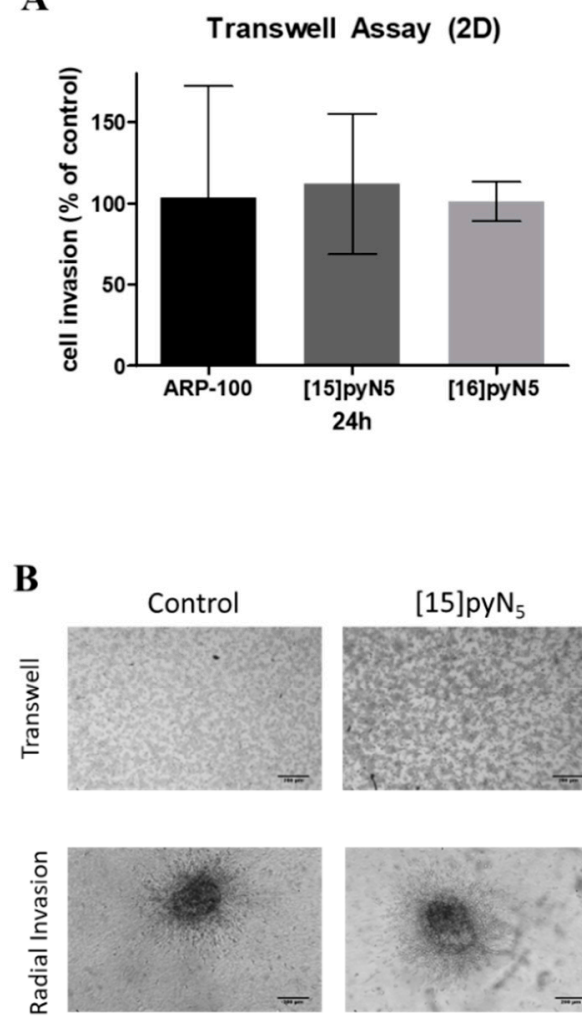

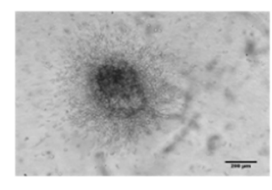

$[15] \mathrm{pyN}_{5}$

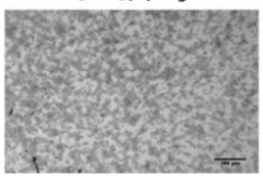

$[16] \mathrm{pyN}_{5}$
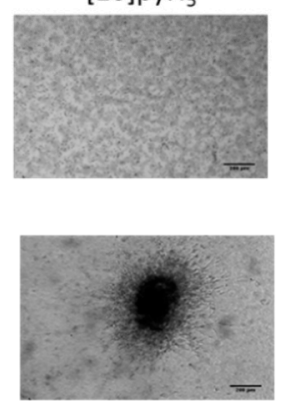

Radial Invasion Assay (3D)

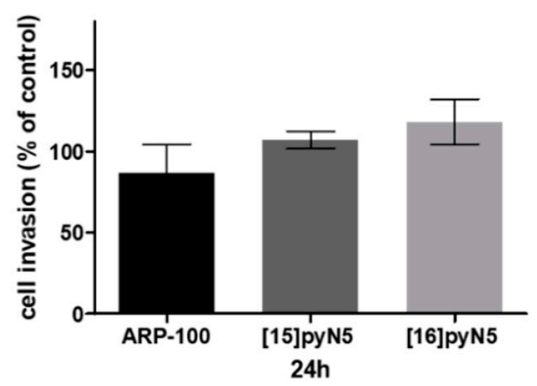

$0.25 \%$ DMSO
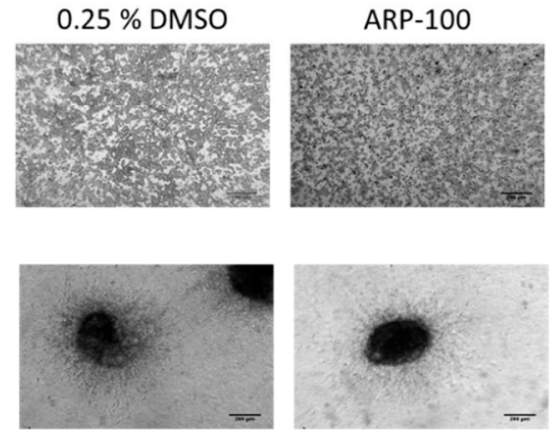

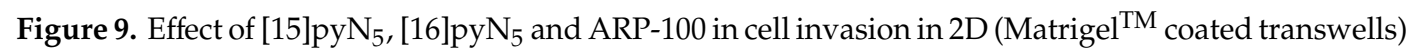
and 3D (radial invasion) models. (A) Quantification of MDA-MB-231 cell invasion after $24 \mathrm{~h}$ in 2D and 3D cultures. Data expressed as percentage (mean $\pm \mathrm{SD}, n=3-4$ ) relative to controls (non-treated condition for [15]pyN $\mathrm{N}_{5}$ and [16]pyN $\mathrm{N}_{5}$ and $0.25 \%$ DMSO for ARP-100); (B) representative images of transwell assays and of radial invasion assays after $24 \mathrm{~h}$ upon incubation with $20 \mu \mathrm{M}$ of each compound and respective controls. Magnification $4 \times$, scale bars $=200 \mu \mathrm{m}$.

\section{Discussion and Conclusions}

In this study a comprehensive multidisciplinary approach combining physiologically relevant in vitro models and docking studies was used for evaluating the MMP-2 and 9 inhibitory potential of two pyridine containing-pentaaza macrocycle compounds for breast cancer therapy.

MDA-MB-231 have been described as highly proliferative triple-negative breast cancer cells belonging to the Basal-like tumors' type [39]. It has also been described as expressing a claudin-low phenotype [40]. Indeed, one of the main differences between basal-like cell lines and the primary tumor 
identified as claudin-low is the proliferation gene cluster, which can be regarded a result of the selection imposed on cell lines under standard in vitro conditions. Moreover, despite several similarities among the basal-like and claudin-low subtypes, it has been even proposed that these two subtypes might not display the same sensitivity to anthracycline/taxane-based chemotherapy treatments [40]. As such, 3D models may provide solid insights that allow for a more competent cell-type/subtype characterization, by revealing information that can be masked under non-physiological culture conditions $[28,29,41]$. In this work, monolayer and spheroid cultures presented relevant differences, particularly in terms of ECM presence and cellular organization inducing different proliferation profiles and gelatinase activity, which translated into different sensitivity to the compounds tested as prospective anti-cancer agents.

Results from cell viability assays showed that MDA-MB-231 in monolayer were significantly more affected by both macrocyclic compounds and ARP-100 when compared to the cells aggregated in spheroids, in which cell viability was consistently higher than $\sim 75 \%$, even for the highest compound concentrations. This 3D-higher cell resistant profile has been proposed to be related to features usually lacking in standard 2D conditions, namely quiescence, ECM-mediated signaling pathways (e.g., apoptotic pathways) [42,43] and even hypoxia-mediated P-glycoprotein up-expression [44]. Thus, similarly to the gradient of nutrients and oxygen, drug penetration is also somewhat hindered in spheroids, once again mimicking the hindered diffusion in solid tumor $[45,46]$. In fact, proliferation marker Ki-67 has been used as a prognostic marker for breast cancer, with reported values under $50 \%$ $\mathrm{Ki}-67^{+}$cells in most in vivo tumors, clearly differing from the $100 \%$ percentage of Ki- $67^{+}$cells present in breast cancer cells cultured in monolayer [39]. Obtaining an in vivo-like proliferation profile is thus vital for a more realistic screening of potential anti-cancer agents, as well as to better understand breast cancer cell heterogeneity and provide a more solid classification.

Besides the differential cell sensitivity and proliferative indices, a culture-dependent gelatinase secretion profile was also observed amongst MDA-MB-231 cells in both culture conditions, with higher expression of MMP-9 and MMP-2 in spheroids and monolayer cultures, respectively. Previous reports stated that MDA-MB-231 cells cultured in a fibronectin coated surface induced both higher expression and activity of MMP-9 [47]. The more complex cell-cell and cell-ECM interactions present in the spheroids might have a role in this secretome change, as cell adhesion molecules such as integrins have been described to modulate MMPs expression [47].

On the other hand, zymography assays performed in this study showed that ARP-100 presents selectivity to MMP-2, with an overall higher inhibition of this gelatinase in both 2D and 3D when compared to MMP-9. This was expected, as this molecule contains an alkyl substituent at the carbon atom adjacent to the hydroxamic acid, that confers lipophilic interactions to the S1 region of the active site, allowing a greater selectivity for MMP-2 in detriment of other MMPs. Notably, both [15]pyN $\mathrm{N}_{5}$ and [16]pyN $\mathrm{N}_{5}$ inhibited gelatinases at concentrations lower than that of ARP-100. Data from the $\mathrm{pZn}^{2+}$ and species distribution for both compounds support their affinity for $\mathrm{Zn}^{2+}$ chelation, which is consistent with their inhibitory effect. Despite its lower interaction towards the $S 1$ pocket due to their structure, both [15]pyN $\mathrm{N}_{5}$ and [16]pyN $\mathrm{N}_{5}$ interactions with $\mathrm{Zn}^{2+}$ may have been the base for this higher inhibition of gelatinases when compared to ARP-100, as MMPs function relies on its structural $\mathrm{Zn}^{2+}$ ion (Figure 6).

Indeed, docking studies confirmed the interaction of the compounds with MMP-2 and MMP-9. The poses' differences observed between MMP-2 and MMP-9 can be explained considering the shapes and the volumes of S1' hydrophobic pockets (Figure 7). Although the structures of MMP-2 and MMP-9 are highly similar the residues comprising the S1' loop share no amino acid sequence similarity and differ in length, justifying the differences observed between the two pockets. [15]pyN $\mathrm{N}_{5}$ and [16]py $\mathrm{N}_{5}$ in particular, appear to be the compounds with higher affinity to MMP-2, presenting an interesting position in $\mathrm{S}^{\prime}$ pocket, namely interacting with His120 ( $\pi-\pi$ interaction) and a Zinc distance similar to the observed for the reference compound ARP-100 (Table 1). The longer distance, and lower interaction, observed between these molecules and S3' pocket residues His84 and Tyr73 can nevertheless be overcome with the design of a chain that is able to strongly interact with these residues. 
Moreover, in order to optimize the interactions between [15]pyN $\mathrm{N}_{5}$ and [16]pyN $\mathrm{N}_{5}$ and $\mathrm{S1}^{\prime}$ pocket of MMP-9, modifications in size of these macrocyclic could be proposed.

Although herein the computational methods show interaction of these py-macrocycles with MMP-2 and 9, due to MMPs highly conserved zinc-dependent catalytic site, [15]pyN $\mathrm{N}_{5}$ and [16]pyN $\mathrm{N}_{5}$ probably also inhibit other MMPs. The importance of MMPs for invasion has been described, but its role in migration per se is still being disclosed. Specifically, in scratch assays, inhibition of MMPs through gene silencing antibody neutralization, and pharmacological inhibitors such as batimastat [11-14] have not been able to completely ablate cell migration. Since in the in vitro scratch assay conditions, MMPs will probably act by cleaving cell-attachment receptors directly, thus modulating cells adhesion during migration [48] and triggering signaling pathways involved in migration and angiogenesis [49]. MMP-1, MMP-9 and MMP-2 were shown to cleave CD44, to cleave CD44 and integrin $\alpha_{M} \beta 2$, and to cleave integrin $\alpha \mathrm{V} \beta 3$ [34,50], respectively, further promoting migration. Besides, it is noteworthy that MMPs function extends beyond proteolytic functions, as their hemopexin domains have been shown to have important roles in migration [51-53]. Indeed, Dufour et al. showed that gelatinase-induced migration did not depend on their proteolytic functions, showing that MMP-9-induced migration was dependent of its hinge and hemopexin domains rather than due its adhesion ability [54]. In this study, MDA-MB-231 cellular migration results also suggest that spheroids are less sensitive than 2D models to the tested compounds. ECM such as Matrigel ${ }^{\mathrm{TM}}$, which was present in the $3 \mathrm{D}$ culture both embedded in the spheroids and in the coating, has been indicated to influence cell migration upon exposure to chemicals. Millerot-Serrurot et al. [55] described that HT1080 cells in 3D collagen I matrix had no significant migration inhibition, at the same doxorubicin concentrations that induced $70 \%$ inhibition in 2D models. Moreover, the GM6001 broad MMPi abrogates ovarian cancer cell monolayers and spheroids migration in collagen I matrix but not in Matrigel $^{\mathrm{TM}}$, showing the relevance of ECM elements for migration and invasion [56]. Moreover, as mentioned above, similarly to in vivo, the compounds might not diffuse completely to the more central zone of the spheroid, affecting just the periphery.

Cellular migration and invasion are two landmark events in cancer progression and metastization. Herein, MDA-MB-231 migration was significantly reduced by the tested compounds, whereas the same was not observed in terms of invasion impairment. The reasons for this differential outcome are not clear and future work is needed to unravel the mechanism underlying this effect. However, it should be noted that cancer cell migration and invasion although coordinately regulated are distinct processes [57].

In sum, the new findings from this study strongly demonstrate that [15]py $\mathrm{N}_{5}$ and [16]pyN $\mathrm{N}_{5}$ are potential inhibitors of MMPs 2 and 9, suggesting its involvement in the observed impaired cell migration of breast cancer cells and therefore reinforcing their potential use as prospective drugs for cancer therapy.

\section{Methods}

\subsection{Chemicals}

Macrocyclic compounds [15]pyN $\mathrm{N}_{5}$ and [16]pyN $\mathrm{N}_{5}$ (Figure 1A) were synthesized in house according to previously described methods [20], using a template procedure for the cyclization (Figure 1B). The macrocycles were prepared in good yields and characterized by ${ }^{1} \mathrm{H}$ and ${ }^{13} \mathrm{C}$ NMR spectroscopy (Tables S1 and S2 and Figures S1 and S2) using a Bruker Avance 400 spectrometer (Bruker BioSpin $\mathrm{GmbH}$, Rheinstetten, Germany) and by Melting points and Elemental analyses using a Leco TruSpec Micro Elemental Analyzer (LECO Corporation, St. Joseph, MI, USA) (see Supplementary information), revealing a very high degree of purity. Aqueous solutions of both compounds were prepared at $2 \mathrm{mM}$, and its exact concentrations were determined by potentiometric titrations.

The aqueous solutions of [15]pyN $\mathrm{N}_{5}$ and [16]pyN $\mathrm{N}_{5}$ used in the studies were prepared by adjusting the $\mathrm{pH}$ to 7.4 with a $\mathrm{KOH}$ solution. Additionally, a $40 \mathrm{mM}$ stock solution of ARP-100 (Santa Cruz 
Biotechnology, CA, USA) was prepared in DMSO (Sigma-Aldrich ${ }^{\circledR}$, St. Louis, MO, USA). Final DMSO concentration was kept at $0.25 \%(v / v)$ in cell cultures throughout the experiments.

\subsection{Cell Culture}

Human breast carcinoma cell line MDA-MB-231 was purchased from ATCC (American Type Culture Collection, Manassas, VA, USA). In monolayer cultures, cells were inoculated in Dulbecco's modified Eagle's medium (DMEM) (Sigma-Aldrich ${ }^{\circledR}$, St. Louis, MO, USA) supplemented with $10 \%$ fetal bovine serum (FBS-Gibco ${ }^{\circledR}$, ThermoFisher Scientific, Waltham, MA, USA).

For spheroid generation, 6-well, 24-wells and 96-wells ultra-low attachment (ULA) flat-bottomed plates (Corning ${ }^{\circledR}$, NY, USA) were inoculated with 250,000 cells/mL in $1500 \mu \mathrm{L} /$ well, $300 \mu \mathrm{L} /$ well and $50 \mu \mathrm{L} /$ well, respectively. Culture medium consisted in DMEM supplemented with 10\% FBS and 2\% Growth Factor Reduced Matrigel ${ }^{\mathrm{TM}}$ (Corning ${ }^{\circledR}, \mathrm{NY}$, USA). Cultures were kept under a humidified atmosphere with $5 \% \mathrm{CO}_{2}$ at $37^{\circ} \mathrm{C}$. Spheroids were then incubated for up to 6 days, with medium replacement every 3 days.

\subsection{Histology}

\subsubsection{Haematoxylin and Eosin (H\&E) Staining}

Cryosections of 5-7 $\mu \mathrm{m}$, prepared from 3D spheroids (from day 4) ressuspended in Tissue Tek ${ }^{\circledR}$ O.C.T. ${ }^{\mathrm{TM}}$ (Sakura, Alphen aan den Rijn, The Netherlands), were fixed with cooled acetone for $10 \mathrm{~min}$. Slides were first stained with Harris's haematoxylin (Sigma-Aldrich ${ }^{\circledR}$, St. Louis, MO, USA) for 20 min, followed by Eosin Y (Sigma-Aldrich ${ }^{\circledR}$, St. Louis, MO, USA) staining for 2 min. Slides were then submitted to increasing concentrations of ethanol and finally incubated in xylene (EMD Chemicals, Burlington, MA, USA). Images were acquired with an Olympus CK30 inverted microscope using Motic Images Version 2.0 software.

\subsubsection{Ki-67 Staining}

Spheroid cryosections were fixed with pre-cooled acetone for $30 \mathrm{~min}$ at $-20^{\circ} \mathrm{C}$, left drying, and then permeabilized with $0.08 \%$ Tween $20^{\circledR}$ for $2 \mathrm{~min}$ at room temperature. This was followed by a 30 min blocking with $2 \%$ bovine serum albumin (BSA) in PBS. Incubation with primary antibody was performed overnight in a humidified chamber at $4{ }^{\circ} \mathrm{C}$. The primary antibody used was: Ki67 (Rabbit IgG, AB16667) (Abcam, Cambridge, United Kingdom) diluted 1:100 in 1\% BSA in PBS. The incubation with the secondary antibody goat anti-rabbit 594 (1:500) (Invitrogen ${ }^{\mathrm{TM}}$, Thermo Fisher Scientific, Waltham, MA, USA) was carried out for $1 \mathrm{~h}$ at room temperature. Sections were mounted using ProLong gold antifade with DAPI (4',6-diamidino-2-phenylindole, Invitrogen $\left.{ }^{\mathrm{TM}}\right)$ and analyzed using an inverted fluorescence microscope (Axiovert 200 M) (Carl Zeiss, Oberkochen, Germany) coupled with a monochrome camera (AxioCam MNC) (Carl Zeiss, Oberkochen, Germany). Sample fluorescence was examined at excitation/emission wavelengths of 590/617 nm (Alexa Fluor 594) and 358/461 (DAPI). Images were collected using AxioVision Rel. 4.7 software.

\subsection{Cell Viability Assays}

The cytotoxicity of [15]pyN $\mathrm{N}_{5}$, [16]pyN $\mathrm{p}_{5}$ and ARP-100, herein used as control, was evaluated in MDA-MB-231 cells in both 2D and 3D culture conditions using CellTiter $96^{\circledR}$ AQueous One Solution Cell Proliferation Assay (MTS) (Promega, Madison, WI, USA). In 2D cultures, $8 \times 10^{3}$ cells were seeded in 96-well plates and maintained for $24 \mathrm{~h}$ in complete culture medium. Thereafter, cells were exposed to $100 \mu \mathrm{L}$ of [15]pyN $\mathrm{N}_{5},\left[16\right.$ pyN $_{5}$ and ARP-100 at final concentrations of 1-100 $\mu \mathrm{M}$, in serum free

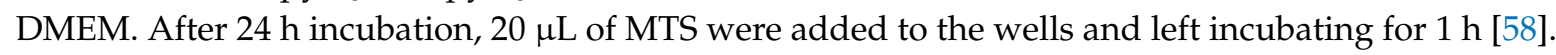
The absorbance was recorded by spectrophotometry at 490 and $690 \mathrm{~nm}$ (SPECTROstar Omega) (BMG LABTECH, Ortenberg, Germany). Three independent experiments were performed. 
In 3D cultures, the cytotoxicity assays were performed in 4-day spheroid cultures in 96-well ULA plates. As such, spheroids' culture medium was replaced by $100 \mu \mathrm{L}$ of DMEM with $1.25 \%$ FBS, $2 \%$ Matrigel $^{\mathrm{TM}}$ and [15]pyN $\mathrm{N}_{5}$, [16]pyN $\mathrm{p}_{5}$ and ARP-100, $(1-100 \mu \mathrm{M})$. After $24 \mathrm{~h}$, spheroids were incubated $1 \mathrm{~h}$ with MTS. Spheroids were pelleted and the supernatant read by spectrophotometry at $490 \mathrm{~nm}$ and $690 \mathrm{~nm}$. The number of viable cells was assessed by the determination of the difference of absorbance, $\mathrm{A}_{490 \mathrm{~nm}}-\mathrm{A}_{690 \mathrm{~nm}}$ and cell viability was expressed as percentage to control. Three independent experiments were performed.

\subsection{Production of Conditioned Media}

For the production of the conditioned medium under 2D conditions (CM2D), $1.5 \times 10^{6}$ MDA-MB-231 cells were seeded in $75 \mathrm{~cm}^{2}$ T-flask for $24 \mathrm{~h}$. At this point, $15 \mathrm{~mL}$ of serum-free DMEM were added to the cells. 3D conditioned medium (CM3D) was performed at day 4 of culture, in 6-well ULA plates. Spheroids were washed twice with serum-free DMEM, and medium was replaced by $2 \mathrm{~mL}$ of serum free DMEM supplemented with $2 \%$ Matrigel $^{\mathrm{TM}}$. In both systems, medium was conditioned for $24 \mathrm{~h}$, being afterwards harvested and concentrated 100× using $10 \mathrm{kDa}$ centrifugal concentrators (Millipore). Total protein was quantified by spectrophotometry (SPECTROstar Omega) (BMG LABTECH, Ortenberg, Germany) in a low volume microplate (Lvis plate) (BMG LABTECH, Ortenberg, Germany). Total protein concentration was determined through Lambert-Beer equation, with absorbance $280-340 \mathrm{~nm}$ and extinction coefficient of bovine serum albumin.

\subsection{Docking Studies}

\subsubsection{Protein and Ligand Structures}

Initial protein structures of MMP-2 and MMP-9, PDB codes: 3AYU and 4XCT (resolution $2.0 \AA$ and $1.3 \AA$ respectively), were selected and obtained from PDB database. The protein structures were prepared using Molecular Operating Environment (MOE) software version 2018.01 (Montreal, QC, Canada). Water molecules and crystallographic ligands were removed from the original crystallographic protein structures. After removal the protein and all the ligands were protonated for the $\mathrm{pH}$ 7.4, using Protonate3D feature implemented in MOE software (some ligands protonation states also adjusted manually). The ligands energies were minimized with Amber2012 force field. The previously prepared ligands were docked into 3AYU and 4XCT protein binding site using GOLD 5.20 (Genetic Optimization for Ligand Docking) software. Default speed settings were accepted and used during the docking simulations. The Genetic Algorithm runs were defined as 500. The 10 best results for each ligand were kept. All the simulations were performed with ChemPLP and GoldScore scoring functions.

To validate the prepared MMP protein structures, a first docking calculation was performed to confirm if the docking protocol followed (protein structure adequacy and all docking parameters) was able to predict ligand poses in agreement with experimental results. In this first docking step, the peptide APP-IP (present in the MMP-2 crystallographic structure, 3AYU) and n73 (N2-[biphenyl-4-yl(dihydroxy)-lambda4-sulfanyl]-N-oxo-N2-(propan-2-yloxy)-D-valinamide, present in the MMP-9 crystallographic structure, 4 XCT) were docked on the respective active sites using a rigid receptor methodology. The top solutions (the 10 poses with the highest score, for each ligand) were critically compared to the crystallographic poses validating our protocol.

After the protocol validation, compounds [15] $\mathrm{pyN}_{5},[16] \mathrm{pyN}_{5}, \mathrm{ARP}-100$ and the commercial specific inhibitors 420121-84-2, 582311-81-7, 848773-43-3, 868368-30-3, Prinomastat, Rebimastat, Ro-28-2653, Sb-3CT, Tanomastat and YHJ-132 (MMP-2 specific) [59-61] were docked into the respective protein active site. The best 10 poses for each compound were critically evaluated inside the pocket and the most important protein-ligand interactions were assessed. Considering the results of Goldscore and ChemPLP scoring functions it was observed that ChemPLP could be the scoring function that better described the system and the binding mode. Only ChemPLP results were discussed. The results are presented as supplementary information (Table S4). 


\subsubsection{MMP-2 and 9 Binding Sites Definition}

The catalytic zinc defined both MMP-2 (2541 atom in 3AYU) and MMP-9 (2404 atom in 4XCT) binding sites. Besides, in MMP-2 two pockets are important to ligands interactions: S1' with His120, Leu82 and Val117; and S3 with Tyr73, His84 and Phe86. In MMP-9 the amino acids Leu187, Leu188, Ala189, His226 and Tyr248 shown to be relevant to establish interactions with known ligands.

\subsection{Modified Zymography Assay}

To evaluate MMP-2 and 9 total gelatinase activity, a zymography was performed using the methodology described in [62] with modifications as depicted in Figure 2. CM concentrated samples were resolved by electrophoresis under non-reducing conditions, in a 10\% Polyacrylamide gel containing $0.1 \%$ SDS and $0.1 \%(w / v)$ gelatin. After electrophoresis, the lanes were individualized and washed with $2.5 \%$ Triton X-100 in 3 steps of $20 \mathrm{~min}$, to remove SDS. Gel lanes were incubated for $24 \mathrm{~h}$ at $37^{\circ} \mathrm{C}$ in Developing Buffer ( $50 \mathrm{mM}$ Tris Base, $200 \mathrm{mM} \mathrm{NaCl}, 5 \mu \mathrm{M} \mathrm{ZnCl} 2,5 \mathrm{mM} \mathrm{CaCl} 2 \cdot 2 \mathrm{H}_{2} \mathrm{O}$ and $0.02 \% \mathrm{NaN}_{3}$ ) containing [15]pyN $\mathrm{N}_{5}$, [16]pyN $\mathrm{P}_{5}$ and ARP-100 $(5-20 \mu \mathrm{M})$. Incubation with developing buffer restores MMPs' protease activity. Therefore, incubations in the absence of compounds were also performed in parallel as control. Finally, gels were stained with $0.1 \%$ Coomassie Brilliant Blue R-250 (National Diagnostics, Charlotte, NC, USA). MMP activity was detected as a clear band in the background of uniform staining. Band quantification was performed using ImageJ software (National Institutes of Health, Bethesda, MD, USA).

\subsection{Migration Assays}

\subsubsection{Scratch Assay}

The effect of pyridine containing macrocycles on cell migration was evaluated through in vitro scratch assay according to previously published procedures [63,64]. Briefly, $2 \times 10^{5}$ MDA-MB-231 cells were seeded in 24-well plates in complete cell culture medium. After $24 \mathrm{~h}$, the medium was removed and a scratch was performed in each well using a 200- $\mu \mathrm{L}$ pipette tip. Cells were then rinsed twice with PBS and kept in serum-free medium containing test compounds [15]py $\mathrm{N}_{5},[16] \mathrm{pyN}_{5}$ or ARP-100 in concentrations ranging from 5-40 $\mu \mathrm{M}$. The scratch was evaluated microscopically (AE 2000 inverted microscope) (Motic, Hong Kong, China), and four images of each scratch were recorded using Moticam 2500 (Motic, Hong Kong, China) at defined time-points: 0, 5, 10 and 24 h. Non-invaded distance was measured using Motic Images PLUS v2.0 software. Three independent experiments were performed.

\subsubsection{Radial Migration}

Radial migration was performed in 3D cultures according to Vinci et al. [26]. Flat-bottomed, 24-well plates (Sarstedt, NC, USA) were coated with $0.01 \mathrm{mg} / \mathrm{mL}$ Poly-D-Lysine (Sigma-Aldrich ${ }^{\circledR}$, St. Louis, MO, USA) in sterile water for $2 \mathrm{~h}$ at room temperature, followed by 1:30 diluted Matrigel ${ }^{\mathrm{TM}}$ coating for $30 \mathrm{~min}$. Four-day spheroids were transferred to pre-coated plates and maintained in $500 \mu \mathrm{L}$ of medium containing $10 \%$ FBS, $2 \%$ Matrigel $^{\mathrm{TM}}$ and the compounds, [15]pyN $\mathrm{N}_{5}$, [16]pyN $\mathrm{N}_{5}$ and ARP-100, in concentrations ranging from 5-40 $\mu \mathrm{M}$. Images were captured at 5, 10 and $24 \mathrm{~h}$ using AE 2000 inverted microscope (Motic, Hong Kong, China) and the area between cells in the migration front and the perimeter of the spheroid measured. More than 10 spheroids per condition were analyzed.

\subsection{Invasion Assays}

\subsubsection{Chemotaxis/Chemoinvasion Assay}

For 2D cultures, the screening of the chemotactic invasion of MDA-MB-231 cells was evaluated in 24 well-plates with transwell inserts (Corning ${ }^{\circledR}, \mathrm{NY}, \mathrm{USA}$ ) coated with a solution of $0.3 \mathrm{mg} / \mathrm{mL}$ Matrigel ${ }^{\mathrm{TM}}$ (Corning ${ }^{\circledR}, \mathrm{NY}, \mathrm{USA}$ ), which blocked the passage of non-invasive cells. After 1-h incubation at $37^{\circ} \mathrm{C}$, the non-polymerized coating was removed. At this point, $5 \times 10^{4}$ cells were briefly seeded in 
the upper chamber in serum free medium. Complete culture medium (chemoattractant) was added to the lower chamber. The test compounds were added to both chambers for a $24 \mathrm{~h}$ period of incubation at $37^{\circ} \mathrm{C}$ in a humidified incubator $\left(5 \% \mathrm{CO}_{2}\right)$. At this point, non-invading cells were removed from the upper part of the inserts with a cotton swab. Cells that invaded towards the underside of the inserts were fixed with $96 \%$ cold ethanol, and then stained in $0.1 \%$ crystal violet solution. Representative images of each condition were taken to measure the stained area. Afterwards membranes were carefully removed from the insert and introduced in Eppendorfs. 10\% acetic acid in ethanol solution was added to solubilize the crystal violet. Measurements were performed in a SPECTROstar Omega (BMG LABTECH, Ortenberg, Germany) multiplate reader at $595 \mathrm{~nm}$ wavelenght.

\subsubsection{Radial Invasion}

Screening of MDA-MB-231 invasion ability as spheroids was evaluated through a radial invasion assay. 4-day spheroids were transferred to flat-bottom 24-well plates (Sarstedt, NC, USA) pre-coated with $250 \mu \mathrm{L}$ of $2 \mathrm{mg} / \mathrm{mL}$ neutralized rat tail Collagen solution [produced in house according to [65] and left incubating for $30 \mathrm{~min}$. Medium was removed and another $250 \mu \mathrm{L}$ of collagen were added over the spheroids, fully covering them. Collagen was allowed to polymerize for $30 \mathrm{~min}$, after which $500 \mu \mathrm{L}$ of media containing the compounds or respective controls was added and the plate and left incubating at $37^{\circ} \mathrm{C}$ in a humidified incubator $\left(5 \% \mathrm{CO}_{2}\right)$. Representative images of the spheroids were taken at 16 and $24 \mathrm{~h}$ and the effects of compounds analyzed by measuring the area between cells in the migration front and the perimeter of the spheroid. More than 10 spheroids per condition were analyzed.

\subsection{Statistical Analysis}

Statistical analyses were carried by GraphPad Prism v6.0 software, (La Jolla, CA, USA). ANOVA with Tukey's multiple comparison post-test was performed for 3 or 4 independent experiments. ANOVA repeated measures tool was used when there were values matching. Results are presented as means \pm standard deviation (SD), except where indicated and $p$-values are presented for statistically significant results $\left({ }^{*} p<0.05,{ }^{* *} p<0.01\right.$ and $\left.{ }^{* * *} p<0.001\right)$.

Supplementary Materials: Supplementary materials can be found at http://www.mdpi.com/1422-0067/20/20/ 5109/s1.

Author Contributions: Conceptualization, J.P.M. and N.G.O; methodology, S.P., B.A., J.C., M.F.C. and F.R.-G.; validation, J.P.M., N.G.O. and R.C.G.; formal analysis, S.P., B.A., J.C., M.F.C. and F.R.-G.; resources, J.P.M., N.G.O. and R.C.G.; data curation, J.P.M., N.G.O. and R.C.G.; writing - original draft preparation, J.P.M., N.G.O. and R.C.G.; writing - review and editing, J.P.M., N.G.O., R.C.G., A.S.F., M.C.; supervision, J.P.M., N.G.O. and R.C.G.; funding acquisition, J.P.M., N.G.O. and R.C.G.

Funding: This work was supported by FCT (Portugal) through the research grant TUBITAK/003/2014.

Acknowledgments: The authors acknowledge Maria J. Villa de Brito and the Centro de Química e Bioquímica e Departamento de Química e Bioquímica, Faculdade de Ciências, Universidade de Lisboa, Portugal, for the NMR spectroscopy. COST Actions (EU Framework Programme Horizon 2020 - CA15135, CA16119 and CA16113) and FCT (UID/DTP/04138/2019, UID/QUI/00100/2019, PTDC/TOX-MED/29183/2017, PDTC/QEQ-MED/7042/2014, PTDC/QUI-QAN/32242/2017 and PD/BD/128320/2017) are also acknowledged.

Conflicts of Interest: The authors declare no conflict of interest. 


\section{Abbreviations}

$3 \mathrm{D}$

three-dimensional

[15]pyN $\quad 3,6,9,12,18$-pentaazabicyclo[1 2.3.1]octadeca-1(18),14,16-triene

[16]pyN $\quad 3,6,10,13,19$-pentaazabicyclo[13.3.1]nonadeca-1(19),15,17-triene

AHA acetohydroxamic acid

ARP-100 2-[([1,1'-biphenyl]-4-ylsulfonyl)(1-methylethoxy)amino]-N-hydroxyacetamide

CM2D Conditioned medium from 2D models

CM3D Conditioned medium from 3D models

DMEM Dulbecco modified eagle modified medium

DMSO dimethylsulfoxide

EDTA ethylenediaminetetraacetic acid

ECM extracellular matrix

EMT epithelial to mesenchymal transition

FBS fetal bovine serum

H\&E hematoxylin and Eosin

MMPi MMP inhibitor(s)

MMPs matrix metalloproteinases

MSS musculoskeletal syndrome

MTS tetrazolium salt 3-(4,5-dimethylthiazol-2-yl)-5-(3-carboxymethoxyphenyl)-2-(4sulfophenyl)-2H-tetrazolium

PAGE polyacrylamide gel electrophoresis

Py-macrocyles pyridine containing macrocycles

SDS Sodium dodecyl sulfate

TIMPs tissue inhibitors of matrix metalloproteinase

ULA ultra low attachment

\section{References}

1. Egeblad, M.; Werb, Z. New functions for the matrix metalloproteinases in cancer progression. Nat. Rev. Cancer 2002, 2, 161-174. [CrossRef] [PubMed]

2. Roy, R.; Yang, J.; Moses, M.A. Matrix Metalloproteinases As Novel Biomarker s and Potential Therapeutic Targets in Human Cancer. J. Clin. Oncol. 2009, 27, 5287-5297. [CrossRef] [PubMed]

3. Li, H.; Cao, D.-C.; Liu, Y.; Hou, Y.-F.; Wu, J.; Lu, J.-S.; Di, G.-H.; Liu, G.; Li, F.-M.; Ou, Z.-L.; et al. Prognostic value of matrix metalloproteinases (MMP-2 and MMP-9) in patients with lymph node-negative breast carcinoma. Breast Cancer Res. Treat. 2004, 88, 75-85. [CrossRef] [PubMed]

4. Leppä, S.; Saarto, T.; Vehmanen, L.; Blomqvist, C.; Elomaa, I. A high serum matrix metalloproteinase-2 level is associated with an adverse prognosis in node-positive breast carcinoma. Clin. Cancer Res. 2004, 10, 1057-1063. [CrossRef]

5. Tauro, M.; Lynch, C. Cutting to the Chase: How Matrix Metalloproteinase-2 Activity Controls Breast-Cancer-to-Bone Metastasis. Cancers 2018, 10, 185. [CrossRef]

6. Bode, W.; Fernandez-Catalan, C.; Grams, H.; Tschesche, F.; Maskos, H.; Nagase, K. Structural properties of matrix metalloproteinases. Cell. Mol. Life Sci. 1999, 55, 639-652. [CrossRef]

7. Köhrmann, A.; Kammerer, U.; Kapp, M.; Dietl, J.; Anacker, J. Expression of matrix metalloproteinases (MMPs) in primary human breast cancer and breast cancer cell lines: New findings and review of the literature. BMC Cancer 2009, 9, 188. [CrossRef]

8. Davies, K.J. The Complex Interaction of Matrix Metalloproteinases in the Migration of Cancer Cells through Breast Tissue Stroma. Int. J. Breast Cancer 2014, 2014, 839094. [CrossRef]

9. Bauvois, B. New facets of matrix metalloproteinases MMP-2 and MMP-9 as cell surface transducers: Outside-in signaling and relationship to tumor progression. Biochim. Biophys. Acta Rev. Cancer 2012, 1825, 29-36. [CrossRef]

10. Bai, X.-Y.; Li, S.; Wang, M.; Li, X.; Yang, Y.; Xu, Z.; Li, B.; Li, Y.; Xia, K.; Chen, H.; et al. Krüppel-like factor 9 down-regulates matrix metalloproteinase 9 transcription and suppresses human breast cancer invasion. Cancer Lett. 2018, 412, 224-235. [CrossRef] 
11. Radisky, E.S.; Radisky, D.C. Matrix metalloproteinases as breast cancer drivers and therapeutic targets. Front. Biosci. (Landmark Ed.) 2015, 20, 1144-1163. [CrossRef] [PubMed]

12. Macaulay, V.M.; O’Byrne, K.J.; Saunders, M.P.; Braybrooke, J.P.; Long, L.; Gleeson, F.; Mason, C.S.; Harris, A.L.; Brown, P.; Talbot, D.C. Phase I study of intrapleural batimastat (BB-94), a matrix metalloproteinase inhibitor, in the treatment of malignant pleural effusions. Clin. Cancer Res. 1999, 5, 513-520. [PubMed]

13. Renkiewicz, R.; Qiu, L.; Lesch, C.; Sun, X.; Devalaraja, R.; Cody, T.; Kaldjian, E.; Welgus, H.; Baragi, V. Broad-spectrum matrix metalloproteinase inhibitor marimastat-induced musculoskeletal side effects in rats. Arthritis Rheum. 2003, 48, 1742-1749. [CrossRef] [PubMed]

14. Fingleton, B. MMPs as therapeutic targets-Still a viable option? Semin. Cell Dev. Biol. 2008, 19, 61-68. [CrossRef] [PubMed]

15. Jacobsen, J.A.; Major Jourden, J.L.; Miller, M.T.; Cohen, S.M. To bind zinc or not to bind zinc: An examination of innovative approaches to improved metalloproteinase inhibition. Biochim. Biophys. Acta - Mol. Cell Res. 2010, 1803, 72-94. [CrossRef] [PubMed]

16. Ndinguri, M.; Bhowmick, M.; Tokmina-Roszyk, D.; Robichaud, T.; Fields, G. Peptide-Based Selective Inhibitors of Matrix Metalloproteinase-Mediated Activities. Molecules 2012, 17, 14230-14248. [CrossRef] [PubMed]

17. Tuccinardi, T.; Martinelli, A.; Nuti, E.; Carelli, P.; Balzano, F.; Uccello-Barretta, G.; Murphy, G.; Rossello, A. Amber force field implementation, molecular modelling study, synthesis and MMP-1/MMP-2 inhibition profile of (R)- and (S)-N-hydroxy-2-(N-isopropoxybiphenyl-4-ylsulfonamido)-3-methylbutanamides. Bioorg. Med. Chem. 2006, 14, 4260-4276. [CrossRef]

18. Jacobsen, F.E.; Lewis, J.A.; Cohen, S.M. A New Role for Old Ligands: Discerning Chelators for Zinc Metalloproteinases. J. Am. Chem. Soc. 2006, 128, 3156-3157. [CrossRef]

19. Hancock, R.D. Chelate ring size and metal ion selection. The basis of selectivity for metal ions in open-chain ligands and macrocycles. J. Chem. Educ. 1992, 69, 615. [CrossRef]

20. Fernandes, A.S.; Cabral, M.F.; Costa, J.; Castro, M.; Delgado, R.; Drew, M.G.B.; Félix, V. Two macrocyclic pentaaza compounds containing pyridine evaluated as novel chelating agents in copper(II) and nickel(II) overload. J. Inorg. Biochem. 2011, 105, 410-419. [CrossRef]

21. Gonçalves, S.; Fernandes, A.S.; Oliveira, N.G.; Marques, J.; Costa, J.; Fátima Cabral, M.; Miranda, J.; Cipriano, M.; Guerreiro, P.S.; Castro, M. Cytotoxic effects of cadmium in mammary epithelial cells: Protective role of the macrocycle [15]pyN $\mathrm{N}_{5}$. Food Chem. Toxicol. 2012, 50, 2180-2187. [CrossRef] [PubMed]

22. Fernandes, A.S.; Flórido, A.; Saraiva, N.; Cerqueira, S.; Ramalhete, S.; Cipriano, M.; Cabral, M.F.; Miranda, J.P.; Castro, M.; Costa, J.; et al. Role of the Copper(II) Complex Cu[15]pyN 5 in Intracellular ROS and Breast Cancer Cell Motility and Invasion. Chem. Biol. Drug Des. 2015, 86, 578-588. [CrossRef] [PubMed]

23. Kim, J.B.; Stein, R.; O'Hare, M.J. Three-dimensional in vitro tissue culture models of breast cancer-A review. Breast Cancer Res. Treat. 2004, 85, 281-291. [CrossRef]

24. dit Faute, M.A.; Laurent, L.; Ploton, D.; Poupon, M.; Jardillier, J.-C.; Bobichon, H. Distinctive alterations of invasiveness, drug resistance and cell-cell organization in 3D-cultures of MCF-7, a human breast cancer cell line, and its multidrug resistant variant. Clin. Exp. Metastasis 2002, 19, 161-167. [CrossRef]

25. Mellor, H.R.; Ferguson, D.J.P.; Callaghan, R. A model of quiescent tumor microregions for evaluating multicellular resistance to chemotherapeutic drugs. Br. J. Cancer 2005, 93, 302-309. [CrossRef]

26. Vinci, M.; Gowan, S.; Boxall, F.; Patterson, L.; Zimmermann, M.; Court, W.; Lomas, C.; Mendiola, M.; Hardisson, D.; Eccles, S. a Advances in establishment and analysis of three-dimensional tumor spheroid-based functional assays for target validation and drug evaluation. BMC Biol. 2012, 10, 29. [CrossRef]

27. Francia, G.; Man, S.; Teicher, B.; Grasso, L.; Kerbel, R.S. Gene Expression Analysis of Tumor Spheroids Reveals a Role for Suppressed DNA Mismatch Repair in Multicellular Resistance to Alkylating Agents. Mol. Cell. Biol. 2004, 24, 6837-6849. [CrossRef]

28. Cipriano, M.; Freyer, N.; Knöspel, F.; Oliveira, N.G.; Barcia, R.; Cruz, P.E.; Cruz, H.; Castro, M.; Santos, J.M.; Zeilinger, K.; et al. Self-assembled 3D spheroids and hollow-fibre bioreactors improve MSC-derived hepatocyte-like cell maturation in vitro. Arch. Toxicol. 2017, 91, 1815-1832. [CrossRef]

29. Pinheiro, P.F.; Pereira, S.A.; Harjivan, S.G.; Martins, I.L.; Marinho, A.T.; Cipriano, M.; Jacob, C.C.; Oliveira, N.G.; Castro, M.F.; Marques, M.M.; et al. Hepatocyte spheroids as a competent in vitro system for drug biotransformation studies: Nevirapine as a bioactivation case study. Arch. Toxicol. 2017, 91, 1199-1211. [CrossRef] 
30. Li, Q.; Chen, C.; Kapadia, A.; Zhou, Q.; Harper, M.K.; Schaack, J.; Labarbera, D. V 3D Models of Epithelial-Mesenchymal Transition in Breast Cancer Metastasis. J. Biomol. Screen. 2011, 16, 141-154. [CrossRef]

31. Vidi, P.-A.; Bissell, M.J.; Lelièvre, S.A. Three-Dimensional Culture of Human Breast Epithelial Cells: The How and the Why. In Epithelial Cell Culture Protocols; Randell, S., Fulcher, M., Eds.; Humana Press: New Jersey, NY, USA, 2012; Volume 945, pp. 193-219.

32. Imamura, Y.; Mukohara, T.; Shimono, Y.; Funakoshi, Y.; Chayahara, N.; Toyoda, M.; Kiyota, N.; Takao, S.; Kono, S.; Nakatsura, T.; et al. Comparison of 2D- and 3D-culture models as drug-testing platforms in breast cancer. Oncol. Rep. 2015, 33, 1837-1843. [CrossRef] [PubMed]

33. Kim, B.J.; Zhao, S.; Bunaciu, R.P.; Yen, A.; Wu, M. A 3D in situ cell counter reveals that breast tumor cell (MDA-MB-231) proliferation rate is reduced by the collagen matrix density. Biotechnol. Prog. 2015, 31, 990-996. [CrossRef] [PubMed]

34. Chetty, C.; Lakka, S.S.; Bhoopathi, P.; Rao, J.S. MMP-2 alters VEGF expression via $\alpha$ V $\beta 3$ integrin-mediated PI3K/AKT signaling in A549 lung cancer cells. Int. J. Cancer 2009, 127, 1081-1095. [CrossRef] [PubMed]

35. Cai, J.; Tang, H.; Xu, L.; Wang, X.; Yang, C.; Ruan, S.; Guo, J.; Hu, S.; Wang, Z. Fibroblasts in omentum activated by tumor cells promote ovarian cancer growth, adhesion and invasiveness. Carcinogenesis 2012, 33, 20-29. [CrossRef]

36. Toth, M.; Sohail, A.; Fridman, R. Assessment of Gelatinases (MMP-2 and MMP-9) by Gelatin Zymography. In Metastasis Research Protocols; Dwek, M., Brooks, S., Schumacher, U., Eds.; Humana Press: New Jersey, NY, USA, 2012; Volume 878, pp. 121-135.

37. Gu, Y.; Lee, H.; Golub, L.M.; Sorsa, T.; Konttinen, Y.T.; Simon, S.R. Inhibition of breast cancer cell extracellular matrix degradative activity by chemically modified tetracyclines. Ann. Med. 2005, 37, 450-460. [CrossRef]

38. Alderighi, L.; Gans, P.; Ienco, A.; Peters, D.; Sabatini, A.; Vacca, A. Hyperquad simulation and speciation (HySS): A utility program for the investigation of equilibria involving soluble and partially soluble species. Coord. Chem. Rev. 1999, 184, 311-318. [CrossRef]

39. Subik, K.; Lee, J.-F.; Baxter, L.; Strzepek, T.; Costello, D.; Crowley, P.; Xing, L.; Hung, M.; Bonfiglio, T.; Hicks, D.G.; et al. The Expression Patterns of ER, PR, HER2, CK5/6, EGFR, Ki-67 and AR by Immunohistochemical Analysis in Breast Cancer Cell Lines. Breast Cancer (Auckl). 2010, 4, 35-41. [CrossRef]

40. Prat, A.; Parker, J.S.; Karginova, O.; Fan, C.; Livasy, C.; Herschkowitz, J.I.; He, X.; Perou, C.M. Phenotypic and molecular characterization of the claudin-low intrinsic subtype of breast cancer. Breast Cancer Res. 2010, 12, R68. [CrossRef]

41. Ivascu, A.; Kubbies, M. Diversity of cell-mediated adhesions in breast cancer spheroids. Int. J. Oncol. 2007, 31, 1403-1413. [CrossRef]

42. Sethi, T.; Rintoul, R.C.; Moore, S.M.; MacKinnon, A.C.; Salter, D.; Choo, C.; Chilvers, E.R.; Dransfield, I.; Donnelly, S.C.; Strieter, R.; et al. Extracellular matrix proteins protect small cell lung cancer cells against apoptosis: A mechanism for small cell lung cancer growth and drug resistance in vivo. Nat. Med. 1999, 5, 662-668. [CrossRef]

43. Weigelt, B.; Lo, A.T.; Park, C.C.; Gray, J.W.; Bissell, M.J. HER2 signaling pathway activation and response of breast cancer cells to HER2-targeting agents is dependent strongly on the 3D microenvironment. Breast Cancer Res. Treat. 2010, 122, 35-43. [CrossRef] [PubMed]

44. Doublier, S.; Belisario, D.C.; Polimeni, M.; Annaratone, L.; Riganti, C.; Allia, E.; Ghigo, D.; Bosia, A.; Sapino, A. HIF-1 activation induces doxorubicin resistance in MCF7 3-D spheroids via P-glycoprotein expression: A potential model of the chemo-resistance of invasive micropapillary carcinoma of the breast. BMC Cancer 2012, 12, 4. [CrossRef] [PubMed]

45. Patel, N.R.; Aryasomayajula, B.; Abouzeid, A.H.; Torchilin, V.P. Cancer cell spheroids for screening of chemotherapeutics and drug-delivery systems. Ther. Deliv. 2015, 6, 509-520. [CrossRef] [PubMed]

46. Minchinton, A.I.; Tannock, I.F. Drug penetration in solid tumors. Nat. Rev. Cancer 2006, 6, 583-592. [CrossRef]

47. Maity, G.; Choudhury, P.R.; Sen, T.; Ganguly, K.K.; Sil, H.; Chatterjee, A. Culture of human breast cancer cell line (MDA-MB-231) on fibronectin-coated surface induces pro-matrix metalloproteinase-9 expression and activity. Tumor Biol. 2011, 32, 129-138. [CrossRef]

48. McCawley, L.J.; Matrisian, L.M. Matrix metalloproteinases: they're not just for matrix anymore! Curr. Opin. Cell Biol. 2001, 13, 534-540. [CrossRef] 
49. Ardi, V.C.; Van den Steen, P.E.; Opdenakker, G.; Schweighofer, B.; Deryugina, E.I.; Quigley, J.P. Neutrophil MMP-9 Proenzyme, Unencumbered by TIMP-1, Undergoes Efficient Activation in Vivo and Catalytically Induces Angiogenesis via a Basic Fibroblast Growth Factor (FGF-2)/FGFR-2 Pathway. J. Biol. Chem. 2009, 284, 25854-25866. [CrossRef]

50. Kajita, M.; Itoh, Y.; Chiba, T.; Mori, H.; Okada, A.; Kinoh, H.; Seiki, M. Membrane-Type 1 Matrix Metalloproteinase Cleaves Cd44 and Promotes Cell Migration. J. Cell Biol. 2001, 153, 893-904. [CrossRef]

51. Correia, A.L.; Mori, H.; Chen, E.I.; Schmitt, F.C.; Bissell, M.J. The hemopexin domain of MMP3 is responsible for mammary epithelial invasion and morphogenesis through extracellular interaction with HSP90. Genes Dev. 2013, 27, 805-817. [CrossRef]

52. Basu, B.; Correa de Sampaio, P.; Mohammed, H.; Fogarasi, M.; Corrie, P.; Watkins, N.A.; Smethurst, P.A.; English, W.R.; Ouwehand, W.H.; Murphy, G. Inhibition of MT1-MMP activity using functional antibody fragments selected against its hemopexin domain. Int. J. Biochem. Cell Biol. 2012, 44, 393-403. [CrossRef]

53. Zaremba-Czogalla, M.; Hryniewicz-Jankowska, A.; Tabola, R.; Nienartowicz, M.; Stach, K.; Wierzbicki, J.; Cirocchi, R.; Ziolkowski, P.; Tabaczar, S.; Augoff, K. A novel regulatory function of CDKN1A/p21 in $\mathrm{TNF} \alpha$-induced matrix metalloproteinase 9-dependent migration and invasion of triple-negative breast cancer cells. Cell Signal. 2018, 47, 27-36. [CrossRef] [PubMed]

54. Dufour, A.; Sampson, N.S.; Zucker, S.; Cao, J. Role of the hemopexin domain of matrix metalloproteinases in cell migration. J. Cell. Physiol. 2008, 217, 643-651. [CrossRef] [PubMed]

55. Millerot-Serrurot, E.; Guilbert, M.; Fourré, N.; Witkowski, W.; Said, G.; Van Gulick, L.; Terryn, C.; Zahm, J.-M.; Garnotel, R.; Jeannesson, P. 3D collagen type I matrix inhibits the antimigratory effect of doxorubicin. Cancer Cell Int. 2010, 10, 26. [CrossRef] [PubMed]

56. Sodek, K.L.; Brown, T.J.; Ringuette, M.J. Collagen I but not Matrigel matrices provide an MMP-dependent barrier to ovarian cancer cell penetration. BMC Cancer 2008, 8, 223. [CrossRef] [PubMed]

57. Menyhárt, O.; Harami-Papp, H.; Sukumar, S.; Schäfer, R.; Magnani, L.; de Barrios, O.; Győrffy, B. Guidelines for the selection of functional assays to evaluate the hallmarks of cancer. Biochim. Biophys. Acta Rev. Cancer 2016, 1866, 300-319. [CrossRef]

58. Guerreiro, P.S.; Corvacho, E.; Costa, J.G.; Saraiva, N.; Fernandes, A.S.; Castro, M.; Miranda, J.P.; Oliveira, N.G. The APE1 redox inhibitor E3330 reduces collective cell migration of human breast cancer cells and decreases chemoinvasion and colony formation when combined with docetaxel. Chem. Biol. Drug Des. 2017, 90, 561-571. [CrossRef]

59. Fisher, J.F.; Mobashery, S. Recent advances in MMP inhibitor design. Cancer Metastasis Rev. 2006, 25, 115-136. [CrossRef]

60. Scatena, R. Prinomastat, a hydroxamate-based matrix metalloproteinase inhibitor. A novel pharmacological approach for tissue remodelling-related diseases. Expert Opin. Investig. Drugs 2000, 9, 2159-2165. [CrossRef]

61. Levin, J.I.; Chen, J.; Du, M.; Hogan, M.; Kincaid, S.; Nelson, F.C.; Venkatesan, A.M.; Wehr, T.; Zask, A.; DiJoseph, J.; et al. The discovery of anthranilic acid-Based MMP inhibitors. Part 2: SAR of the 5-position and P11 groups. Bioorg. Med. Chem. Lett. 2001, 11, 2189-2192. [CrossRef]

62. Santos, J.M.; Camões, S.P.; Filipe, E.; Cipriano, M.; Barcia, R.N.; Filipe, M.; Teixeira, M.; Simões, S.; Gaspar, M.; Mosqueira, D.; et al. Three-dimensional spheroid cell culture of umbilical cord tissue-derived mesenchymal stromal cells leads to enhanced paracrine induction of wound healing. Stem Cell Res. Ther. 2015, 6, 90. [CrossRef]

63. Liang, C.-C.; Park, A.Y.; Guan, J.-L. In vitro scratch assay: A convenient and inexpensive method for analysis of cell migration in vitro. Nat. Protoc. 2007, 2, 329-333. [CrossRef] [PubMed]

64. Flórido, A.; Saraiva, N.; Cerqueira, S.; Almeida, N.; Parsons, M.; Batinic-Haberle, I.; Miranda, J.P.; Costa, J.G.; Carrara, G.; Castro, M.; et al. The manganese(III) porphyrin MnTnHex-2-PyP5+ modulates intracellular ROS and breast cancer cell migration: Impact on doxorubicin-treated cells. Redox Biol. 2019, 20, 367-378. [CrossRef] [PubMed]

65. Rajan, N.; Habermehl, J.; Coté, M.-F.; Doillon, C.J.; Mantovani, D. Preparation of ready-to-use, storable and reconstituted type I collagen from rat tail tendon for tissue engineering applications. Nat. Protoc. 2007, 1, 2753-2758. [CrossRef] [PubMed] 
(C) 2019 by the authors. Licensee MDPI, Basel, Switzerland. This article is an open access article distributed under the terms and conditions of the Creative Commons Attribution (CC BY) license (http://creativecommons.org/licenses/by/4.0/). 